\title{
Uluslararası Finansal Raporlama Standartları ile Türk Bankacılık Sektörü Kâr Kalitesi Arasındaki İlişkiye Bir Bakış
}

\author{
Merve ACAR * \\ Burcu GÜROL **
}

\section{ÖZET}

Finansal sistemin en önemli kurumları arasında yeralan bankaların sundukları finansal tablolar, yatırımcı ve müşsteri sayılarının fazlalığı, faaliyetlerinin ülke/ülkeler ekonomilerini etkileme gücü vb. nedenlerle birçok kullanıcı tarafindan kullanılmaktadır. Kullanıcıların finansal tabloları hazırlayanlardan beklentileri, finansal tablo kalite düzeylerinin yüksek olmasıdır. Kâr yönetimi ve sermaye yönetimi uygulamaları finansal tablo kalite düzeyini olumsuz etkilemektedir. Bu çalışmada, amacı finansal tabloların kalite ve karşılaş̧ırllabilirlik düzeylerini artırmak olan Uluslararası Finansal Raporlama Standartları'nın Türk Bankacılık sisteminin kâr ve sermaye yönetimi uygulamaları üzerindeki etkisi görülmeye çalışılmıştır. Elde edilen sonuçlara göre Türk Bankacılık sektörü kredi ve diğer alacaklar değer düşüklüğ̈̈ karşılıkları aracıllğ̆yla sinırlar dahilinde kâr ve sermaye yönetimi faaliyetlerinde bulunmaktadır. Diğer taraftan Uluslararası Finansal Raporlama Standartları'na geçiş ile kâr yönetimi davranışında azalış gözlemlenirken UFRS sonrası sermaye yönetimi faaliyetlerinde anlamlı bir değişim gözlemlenmemiştir.

Anahtar Kelimeler: Bankalar, Kâr Yönetimi, Sermaye Yönetimi, Banka Finansal Tabloları, UFRS, Finansal Tablolarda Kalite, Muhasebe Kalitesi, Kredi Kayıp Karşılıkları.

JEL Sinıflandırması: G21, M40, M41.

\section{A Perspective on Association Between International Financial Reporting Standards and Earnings Quality of Turkish Banking Sector \\ ABSTRACT}

Banks are the among the most important institutions of the financial system. Bank financial statements are used by many users for many reasons such as the number of investors and customers and the power of their activities affecting the economies of the country/countries. The users of the financial statements expects high quality reporting from the preparers. Earnings management and capital management practices adversely affect the quality of the financial statement. In this study, impact of the use of International Financial Reporting Standards, which aims to increase the quality and comparability levels of the financial statements, on the earnings and capital management practices is analyzed for the Turkish banking system. According to the results, banks are using loan loss provisions for earnings and capital management purposes. Significant decrease has been observed for earnings management activities for post-IFRS period, however IFRS resulted in no significant change for capital management activities.

Keywords: Banks, Earnings Management, Capital Management, Bank Financial Statements, IFRS, Financial Statements Quality, Accounting Quality, Loan Loss Provisions.

Jel Classification: G21, M40, M41.

\footnotetext{
* Dr. Merve Acar, Yıldırım Beyazıt Üniversitesi, İşletme Fakültesi, merve-hun@hotmail.com

** Dr. Burcu Gürol, Başkent Üniversitesi, Ticari Bilimler Fakültesi, bgurol@baskent.edu.tr
} 


\section{GiRiș}

Türkiye'de finansal kurumlara bakıldığında birçok ülke ile benzer şekilde bankaların finansal sistemin en büyük kurumları oldukları görülmektedir. Türkiye Bankalar Birliği'nin (TBB) verilerine göre Haziran 2016 tarihi itibariyle sektörün aktif toplamı yaklaşık 2,5 trilyon TL'ye ulaşmıştır. Gerek sektörün bu denli büyük oluşu gerekse mudi, çalışan, borç veren sayılarının fazlalığı nedeniyle bankaların hazırlayıp sundukları finansal tablolar birçok gerçek ya da tüzel kişi tarafından kullanılmaktadır. Kullanıcılar bu finansal tablolar üzerinden ekonomik kararlar almaktadırlar. Bu sebeple söz konusu finansal tabloların ait olduğu bankanın gerçek durumunu gösterir nitelikte olmaktan uzaklaşması yatırımcıların ve mudilerin para kaybetmelerine, bankalara yatırım yapmaktan uzaklaşmalarına, finansal sistemin ihtiyacı olan fonu temin edememesine ve fon eksiği olanlara kaynak sağlayamamasına neden olabilmektedir. Tüm bu olumsuz tablonun yaşanmaması için sunulan finansal tabloların kalite ve karşılaştırılabilirlik düzeylerinin yüksek olması büyük önem taşımaktadır.

Finansal tablolarda kalite kavramı net olarak bir tanımlamaya sahip değildir. Gençoğlu ve Ertan bu kavramı finansal tablolarda yer alan bilgilerin, finansal tablo kullanıcilarının ihtiyaçlarına uygun olması olarak tanımlamaktadırlar (2012). Bankacılık sektörü üzerinde yapılan çalışmalarda finansal tabloların kalitesi, kâr kalitesi kavramı üzerinden açıklanmaktadır. Kâr kalitesi, tahakkukların kalitesi ile ilgilidir. Tahakkukların yatırımcıları gelecek nakit akışları hakkında tahminlerde bulunarak bilgilendirme işlevleri yanında, ne yazık ki yöneticiler tarafindan raporlanan kârları manipüle ederek finansal tablo kullanıcısına gerçeğe aykırı bilgi verme gibi çıkarlar çerçevesinde kötüye kullanılma gibi işlevleri de bulunmaktadır (Bannister ve Newman 1996, Dechow ve Dichev 2002, DeFond ve Jiambalvo 1994, McNichols 2002, Plenborg 1996, Richardson ve diğerleri 2005, Sloan 1996).

Finansal sektör kâr kalitesinin ele alındığı bu çalışmada, gerek kâr yönetimi gerek sermaye yönetimi açısından incelenen "kâr kalitesi" bankacılık sektörünün nitelik ve nicelik açısından en ön plana çıkan tahakkuk kalemi olan "kredi ve diğer alacaklar değer düşüklüğü karşılıkları” ${ }^{1}$ (loan loss provisions/LLP) aracılığıyla ele alınmıştır. Çalışma kapsamında Türkiye'de 2003-2015 yılları arasında faaliyette bulunmuş 24 bankanın bu yıllar arasında yayınladıkları yılsonu finansal tabloları üzerinden oluşturulan veri seti panel veri analiz teknikleri uygulanarak analiz edilmiş ve Türk Bankacılık sisteminde kredi kayıp ve karşılıkları ile karşılık öncesi net kâr ve sermaye yeterlilik oranı arasında ilişki bulunup bulunmadığı ve Uluslararası Finansal Raporlama Standartlarının (UFRS) bu ilişkileri ne yönde etkilediği sonuçlarına ulaşılmaya çalışılmıştır. Çalışma kapsamına 2003-2015 yılları arasında yayınlanan finansal tabloların alınmasının sebebi 2005 yılından itibaren Türk bankalarının UFRS uyumlu finansal raporlama yapmaya başlamaları ve bu etkinin

\footnotetext{
${ }^{1}$ Çalışmanın geri kalan kısmında kredi ve diğer alacaklar değer düşüklüğü karşılıklarından “LLP” olarak
} bahsedilecektir. 
görülebilmesi için öncesinde ve sonrasında yayınlanan finansal tabloların analiz edilmelerinin gerekliliğidir. 2003 yılından itibaren finansal tabloların alınmasının nedeni, daha önceki yıllarda 2001 yılında yaşanan bankacılık krizinin etkilerinin görülmesidir. Sonuçların kalite düzeylerini artırmak amacıyla veri seti hazırlanırken2005 yılından sonraki dönem olarak ise 2015 yılı finansal tabloları da dahil olmak üzere 10 yıllık finansal tablolar çalışma kapsamına alınmıştır.

\section{LITERATÜR TARAMASI}

Uluslararası Muhasebe Standartları Kurulu'nun (IASB) temel amac1, tüm dünya çapında sermaye piyasası katılımcıları ve diğer finansal tablo kullanıcılarının karar verme süreçlerinde kullanacakları yüksek kaliteli, şeffaf ve karşılaştırılabilir bilgiye sahip finansal tabloların hazırlanabilmesi için kaliteli, anlaşılabilir ve uygulanabilir bir ortak finansal raporlama dili olan uluslararası muhasebe standartları oluşturmaktır (Epstein ve Mirza 1997). Bu kapsamda UFRS’nin finansal tablolarda yer alan bilgilerin doğruluğunu, güvenilirliğini ve karşılaştırılabilirliğini arttırmak konularında öne çıktığı söylenebilir. Bushman ve Smith (2001) UFRS sonrasında yatırımcılarla şirketler arasında bilgi asimetrisinin azaldığını raporlayarak daha kaliteli ve karar verme süreçlerini olumlu yönde etkileyen finansal raporların hazırlandığını belirtmiştir. Diğer taraftan UFRS sayesinde yatırımcılar şirketlerin gelecek finansal performansları hakkında daha yerinde ve doğru tahminler yapabilmektedirler (Street ve diğerleri 2000). UFRS uygulamalarının şirketlerin finansal performansları ve finansal tablo kalitesi üzerinde olumlu etkileri olduğuna dair literatürde daha pek çok çalışma bulunmaktadır (Callao ve diğerleri 2014, Holthausen 1990, Jermakowicz 2004, Street ve diğerleri 2000, Tarca 2004, Van Tendeloo ve Vanstraelen 2005).

Bu kapsamda bu çalışma Türkiye'de UFRS uygulamalarının bankacılık sektörü kâr kalitesi üzerindeki etkisini ortaya koymayı amaçlamıştır. Kâr kalitesi ise; kâr yönetimi ve sermaye yönetimi uygulamaları, bir diğer ifadeyle tahakkuk kalitesi dikkate alınarak ölçülmüştür. Bu kapsamda literatürde kâr kalitesini tahakkuk kalitesi aracılığıyla ölçen ve tahakkuk kalitesi yüksek olan işletmelerin kâr kalitesinin de yüksek olduğu çıkarımını yapan pek çok çalışma bulunmaktadır (Boonlert-U-Thai ve diğerleri 2006, Francis ve diğerleri 2004, Rahman ve diğerleri 2010).

\subsection{Kâr Yönetimi Uygulamaları: Kârın İstikrarlı Gösterilmesi}

Çalışma kapsamında Türk finans sektörü, kâr yönetimi uygulamalarından "kârın istikrarlı gösterilmesi” ele alınmış ve incelenmiştir. Muhasebeleştirme manipülasyonları arasında gösterilen kâr yönetimi en genel şekliyle, yöneticilerin şirket performansı hakkında piyasa katılımcılarını yanlış yönlendirmek ya da raporlanan kâr bilgisine göre şekillenen bazı sözleşmelerden doğan sonuçları etkilemek amacıyla, kendilerine tanınan karar verme yetkisini kullanarak, finansal raporlarda yer alan bilgileri aslına uygun bir şeklinde yayınlamamalarıdır (Mulford ve Comiskey 2011). Raporlanan kâr; özellikle ek ödenek ve primlerin belirlenmesi, 
borç sözleşmeleri, proje değerleme, halka arz edilme gibi geniş bir piyasa kitlesine hitap eden ve muhasebenin tahakkuk esası çerçevesinde firmanın performansı hakkında özet bilgi sunan en önemli kalemlerden biri olarak karşımıza çıkar(Dechow 1994). Piyasa katılımcıları finansal tablolarda yer alan kâr tutarını o kadar önemserler ki çoğu zaman sadece kâra odaklanıp onu meydana getiren bileşen ve süreçlerle özellikle de kârın tahakkuk bileşeniyle ilgilenmez, karar verme süreçlerinde miyop davranış sergilerler (Bradshaw ve diğerleri 2001, Richardson ve diğerleri 2005, Sloan 1996).

Çalışmada test edilecek olan "kârın istikrarlı gösterilmesi" hipotezi, literatürde kâr yönetimi çerçevesinde geliştirilen özel bir muhasebeleştirme manipülasyonu olarak ele alınmaktadır. En genel ifadeyle kârın istikrarlı gösterilmesi, uygun muhasebe ilke, yöntem ve politikaları aracılı̆̆ıla kârdaki dalgalanmaların azaltılarak hedef kâr düzeyine çekilmesidir (Copeland 1968). Bu çalışma kapsamında kârın istikrarlı gösterilmesi hipotezi finansal sektör çerçevesinde ele alınmışıır; ancak bu kâr yönetimi uygulamasını reel sektör üzerinde de test eden birçok çalışma vardır (Bao ve Bao 2004, Beidleman 1973, Breton ve Stolowy 2000, Cahan 1992, Dechow ve Skinner 2000, DeFond ve Park 1997, Fudenberg ve Tirole 1995, Imhoff 1979, Martinez ve Castro 2011, Michelson ve diğerleri 1995, Stolowy ve Breton 2004, Trueman ve Titman 1988, White 1970).

Finansal sektör açısından ele alındığında, kârın istikrarlı gösterilmesi uygulaması raporlanan muhasebe kârının ekonomik kâra kıyasla daha istikrarlı görünmesini sağlayan, bir bakıma kârdaki dip ve tepe noktalarını törpüleyerek kârda dönemler arası dengeli bir seyir elde etmeyi amaçlayan uygulamalar olarak tanımlanabilir (Ma 1988). Bu durum ekonomik olarak elde edilen kârın bazen olduğundan yüksek bazen de düşük gösterilerek istikrarlı hale getirilmesi ve bu sayede bankanın finansal gücüne ve kalitesine ilişkin algıyı kuvvetlendirmek olarak ortaya çıkar (Beidleman 1973, Bhat 1996).

Bankacılık sektöründe kârın istikrarlı gösterilmesine dair ilk çalışma Scheiner (1981) tarafindan yapılmıştır; ancak Scheiner (1981) olağan kâr ile LLP arasında pozitif ilişki saptayamamış, dolayısıyla bankaların kârı istikrarlı gösterdiği yönünde kurulan hipotezi destekleyememiştir. Yapılan çalışmaların çoğu ABD bankaları üzerine yapılmakla beraber ulaşılan sonuçların hemen hepsi kârın istikrarlı gösterilmesi hipotezini desteklemektedir (Ali ve diğerleri 2015, Beaver ve Engel 1996, Bhat ve diğerleri 2014, Bhat 1996, Blasco ve Pelegrin 2006, Bushman ve Williams 2012, Cavallo ve Majnoni 2002, Collins ve diğerleri 1995, Curcio ve Hasan 2008, Curcio ve Hasan 2015, El Sood 2012, Greenawalt ve Sinkey Jr 1988, Hasan ve Wall 2004, Kanagaretnam ve diğerleri 2003, Kanagaretnam ve diğerleri 2004, Kim 2013, Kwak ve diğerleri 2009, Lobo ve Yang 2001, Moyer 1990, Rivard ve diğerleri 2003, Scholes ve diğerleri 1990). Tablo 1'de finansal sektörde (bankacılık sektörü) kârın istikrarlı gösterilmesi alanında yapılan çalışmalar özetlenmektedir ${ }^{2}$

\footnotetext{
${ }^{2}$ Tablonun oluşturulmasında büyük ölçüde Temiz vd. (2016) çalışmasından yararlanılmıştır.
} 
Tablo 1. Kâr Yönetimi Alanında Finansal Sektör İçin Yapılan Çalışmalar

\begin{tabular}{|c|c|}
\hline YAZAR & KONUSU VE ULAŞILAN SON \\
\hline 81) & $\begin{array}{l}\text { 1969-1976 yılları arasında ABD'de faaliyet gösteren } 107 \text { banka holding şirketinin LLP ile kârı istikrarlı gösterme durumları incelenmiştir. } \\
\text { SONUÇ: Faaliyet kârı ile LLP arasında anlamlı pozitif ilişki saptanmamıştır. Sadece } 23 \text { bankada (örneklemin \%21,5’i) kârın istikrarlı gösterilmesi hipotezi } \\
\text { desteklenmiştir. }\end{array}$ \\
\hline Ma (1 & $\begin{array}{l}\text { 1980-1984 dönemi için THE AMERICAN BANKER'de yer alan en büyük } 45 \text { banka örneklem olarak seçilmiş ve LLP ile faaliyet kârı arasındaki ilişki analiz edilmiştir. } \\
\text { sONUC: Örneklemdeki bankalar LLP ve aktiften silinen krediler ile kârı istikrarlı hale getirmektedirler. }\end{array}$ \\
\hline $\begin{array}{l}\text { Greenawalt ve } \\
\text { Sinkey Jr (1988) }\end{array}$ & $\begin{array}{l}\text { 1976-1984 dönemi için Compustat’ta yer alan } 106 \text { banka holding şirketinin kâr yönetimi davranışı incelenmiştir. } \\
\text { SONUC: Kredi portföy kalitesine ve makroekonomik faktörlere ilişkin kontrol değişkenlerinin de dikkate alınması sonucu, bankaların LLP'yi kârı istikrarlı göstermek içi } \\
\text { kullandıkları sonucuna ulaşılmıştır. }\end{array}$ \\
\hline $\begin{array}{l}\text { Collins ve diğerleri } \\
\text { (1995) }\end{array}$ & $\begin{array}{l}\text { 971-1991 dönemi için Compustat’ta yer alan } 160 \text { bankaya ait LLP kâr ve sermaye yönetimi açısından incelenmiştir. } \\
\text { ONUC::LLP sadece kâr yönetimi için kullanılmaktadır. Aktiften silinen krediler ve menkul kıymet ihracı ise sadece sermaye yönetiminde kullanılmaktadır. }\end{array}$ \\
\hline Bhat & $\begin{array}{l}\text { 1981-1991 dönemi için ABD bankalarının karşılıklar ile kâr yönetimi yapıp yapmadıkları ve eğer yapıyorlarsa bu bankaların sahip olduğu özellikler sorgulanmıştır. } \\
\text { sONUC::LLP aracılığı ile kâr yönetimi yaparak kârını istikrarlı gösteren bankalar, büyüme hızı düşük, düşük defter değeri/varlık değerine sahip, yüksek kredi/mevduat ve } \\
\text { kredi/varlık oranına sahip, piyasa değeri/defter değeri düşük, varlıklarının kârlılığı düşük, yüksek LLP/brüt krediler oranına sahip küçük, kredi portföyünde yüksek riskli } \\
\text { kredilerin çoğunlukla bulunduğu, finansal durumları iyi olmayan bankalardır. }\end{array}$ \\
\hline $\begin{array}{l}\text { Ahmed ve } \\
\text { diğerleri (1999) }\end{array}$ & $\begin{array}{l}\text { 1987-1995 dönemi için ABD’de faaliyet gösteren } 113 \text { bankanın LLP kâr yönetimi, sermaye yönetimi ve sinyal verme rolü kapsamında analiz edilmiştir. Bahsi geçen } \\
\text { ilişkilerin } 1990 \text { sermaye yeterlilik düzenlemeleri sonucu nasıl değiştiği sorgulanmıştır. } \\
\text { sONUC: LLP ile sermaye yeterlilik oranı arasında negatif ilişki bulunmuştur (sermaye yönetimi yapılmaktadır), bu ilişki düzenlemeler sonrasında değişmemiştir. Kârın } \\
\text { istikrarlı gösterilmesine ve karşılıkların piyasaya olumlu sinyal verme rolüne rastlanılmamıştır. }\end{array}$ \\
\hline $\begin{array}{l}\text { Cavallo ve } \\
\text { Majnoni (2002) }\end{array}$ & $\begin{array}{l}\text { 1988-1999 dönemi için G10 üyesi ülkelerle (Belçika, Kanada, Fransa, Almanya, İtalya, Japonya, Hollanda, İsviçre, İsveç, Birleşik Krallık, Amerika Birleşik Devletleri) } \\
\text { G10 üyesi olmayan } 26 \text { ülke bankası kârın istikrarlı gösterilmesi kapsamında analiz edilmiştir. } \\
\text { sONUC:: G10 ülkelerinde karşlıklar ile kâr arasında güçlü bir pozitif ilişki vardır, dolayısıyla bankalar kârı istikrarlı göstermektedirler. Ancak G10 ülkesi olmayan } \\
\text { ülkelerin oluşturduğu veri setindeki bankalar için karşılıklar ile kâr arasında negatif ilişki saptanmakla beraber ilişki istatistiksel olarak anlamlı çıkmamıştır. }\end{array}$ \\
\hline
\end{tabular}


Tablo 1. (Devami)

\begin{tabular}{|c|c|}
\hline YAZAR & ARAŞTIRMA KONUSU VE ULAŞILAN SONUÇLAR \\
\hline Shrieves ve Dahl (2003) & $\begin{array}{l}\text { 1989-1996 dönemi için Japonya’da faaliyet gösteren bankalar analiz edilmiştir. Basel düzenlemelerinin Japon bankacılık sektöründe kâr yönetimi üzerindeki } \\
\text { etkisi sorgulanmıştır. } \\
\text { SONUC:Japon bankaları LLP ve menkul kıymet kazançları aracılığıyla kârı istikrarlı göstermektedirler. Basel düzenlemeleri sonrasında kâr yönetimi } \\
\text { uygulamalarında azalma gözlemlenmiştir. }\end{array}$ \\
\hline $\begin{array}{l}\text { Kanagaretnam ve diğerleri } \\
\text { (2003), Kanagaretnam ve } \\
\text { diğerleri (2004) }\end{array}$ & $\begin{array}{l}\text { Yöneticileri kârı istikrarlı göstermeye iten nedenleri 1987-2000 yılları için ABD’de faaliyet gösteren banka holding şirketleri için ortaya koymaya } \\
\text { çalışmışlardır. 1980-1997 dönemi için Compustat veri tabanında listelenen bankaların LLP kâr yönetimi ve sinyal verme rolü kapsamında analiz edilmiştir. } \\
\text { SONUC: } \text {. Ulaşılan sonuçlara göre, banka yöneticileri performansın iyi olduğu dönemlerde (yüksek kâr açıklanan dönemler) karşılıklarını arttırarak bir çeşit } \\
\text { tasarrufta bulunmakta, kötü dönemlerde (düşük kâr açıklanan dönemler) ise karşılıklarını azaltarak geleceğe borçlanmaktadırlar. Bu bulgular kârın istikrarlı } \\
\text { gösterildiğini ve bunun iş güvenliği hakkındaki endişeler yüzünden yapıldığını desteklemektedir. Ayrıca çalışmaya göre kârın istikrarlı gösterilmesini } \\
\text { etkileyen bir diğer faktör de işletme dışı finansman sağlama ihtiyacıdır. Kârın istikrarlı gösterilmesi ve ihtiyari karşılıklarla piyasaya olumlu mesaj verme rolü } \\
\text { bulgularla desteklenmiştir. }\end{array}$ \\
\hline Hasan ve Wall (2004) & $\begin{array}{l}\text { 1993-2000 dönemleri için ABD, Japonya ve Kanada'da faaliyet gösteren bankaların kâr yönetimi davranışı incelenmiştir. } \\
\text { SONUC: Kanada'da faaliyet gösteren bankalar dışındaki tüm bankalar kârı istikrarlı göstermek için özel karşılıkları kullanmaktadır. Kâr yönetiminin } \\
\text { yoğunluğu ise ABD’de faaliyet gösteren bankalarda Japonya'da faaliyet gösterenlere göre daha azdır. }\end{array}$ \\
\hline Anandarajan ve diğerleri (2005) & $\begin{array}{l}\text { 1986-1995 döneminin analiz edildiği çalışmada yatırım ve mevduat bankalarının kâr yönetimi, sermaye yönetimi ve sinyal verme davranışları incelenmiştir. } \\
\text { SONUC::LLP kâr yönetimi ve sermaye yönetimi kapsamında yöneticiler tarafından kullanılmaktadır. Ancak Basel düzenlemeleri sonrasında LLP’nin sermaye } \\
\text { yönetiminde kullanılma rolü kalmamış, kâr yönetimi uygulamaları ise hız kazanmıştır. Ayrıca mevduat bankaları yatırım bankaları ile kıyaslanınca daha çok } \\
\text { kâr yönetimi yapmaktadırlar. Sinyal verme hipotezi ise reddedilmiştir. }\end{array}$ \\
\hline Pérez ve diğerleri (2008) & $\begin{array}{l}\text { 1986-2002 yıllarında İspanya'da faaliyet gösteren bankaların kâr ve sermaye yönetimi davranışları incelenmiştir. } \\
\text { SONUC:LLP'nin kâr yönetimi amacıyla kullanıldığı ancak sermaye yönetimi alanında kullanılmadığı sonucuna ulaşılmıştır. }\end{array}$ \\
\hline Fonseca ve González (2008) & $\begin{array}{l}\text { 1995-2002 yıllarının ele alındığı çalışmada } 40 \text { ülkeye ait bankacılık verisi kullanılarak kârın istikrarlı gösterilmesi hipotezi uluslararası bir örneklem } \\
\text { çerçevesinde incelenmiştir. } \\
\text { SONUCC:Kârın istikrarlı gösterilmesi hipotezini destekleyici sonuçlar elde edilmiştir. Ülke bazında denetim faaliyetleri arttıkça ya da küçük yatırımcıyı } \\
\text { koruyan yasalar düzenlendikçe kâr yönetimi faaliyetleri de azalmaktadır. }\end{array}$ \\
\hline
\end{tabular}




\begin{tabular}{|c|c|}
\hline YAZAR & ARAŞTIRMA KONUSU VE ULAŞILAN SONUÇLAR \\
\hline $\begin{array}{l}\text { Bouvatier ve Lepetit } \\
\text { (2008) }\end{array}$ & $\begin{array}{l}\text { 1992-2014 dönemi için Avrupa'da faaliyet gösteren örneklem dahilinde } 15 \text { ülke bankasının kâr yönetimi, sermaye yönetimi ve piyasaya sinyal verme rolleri analiz } \\
\text { edilmiştir. } \\
\text { SONUÇ:LLP ile kâr arasında anlamlı negatif ilişki saptanmış, kârın istikrarlı gösterilmesi hipotezi reddedilmiştir. Sermaye yönetimi ve sinyal verme hipotezleri ise } \\
\text { desteklenmiştir. }\end{array}$ \\
\hline $\begin{array}{l}\text { Curcio ve Hasan } \\
\text { (2008) }\end{array}$ & $\begin{array}{l}\text { 1996-2006 dönemleri için } 2004 \text { yılı öncesinde AB üyesi ülkeler (15 ülke), } 2004 \text { yılında üye olan ülkeler (10) ve } 2006 \text { yılı itibariyle birliğe üye olmayan } 23 \text { ülke bankas1 } \\
\text { kâr yönetimi, sermaye yönetimi ve sinyal verme hipotezleri kapsamında analiz edilmiştir. } \\
\text { sONUCC: Analiz edilen tüm ülkeler karş1lıklar aracılığıyla kârı istikrarlı göstermektedir. Sermaye yönetimi uygulamalarına AB ülkelerinde, piyasaya ihtiyari karş1lıları } \\
\text { arttırarak olumlu sinyal verme davranışı ise sadece AB'ye üye olmayan ülkelerde gözlemlenmiştir. }\end{array}$ \\
\hline $\begin{array}{l}\text { Kwak ve diğerleri } \\
\text { (2009) }\end{array}$ & $\begin{array}{l}\text { 1991-1999 yılları için Japonya'da faaliyet gösteren bankaların LLP ile kâr yönetimi davranışları incelenmiştir. } \\
\text { SONUC:Kâr yönetimini sahiplik yapısı çerçevesinde analiz eden çalışmada kârın istikrarlı gösterilmesi hipotezi desteklenmekle birlikte, banka paylarında kurumsal } \\
\text { yatırımcı ve finansal kuruluş ağırlığı arttıkça daha agresif bir şekilde kâr yönetimi yapıldığı raporlanmıştır. }\end{array}$ \\
\hline $\begin{array}{l}\text { Leventis ve diğerleri } \\
\text { (2011) }\end{array}$ & $\begin{array}{l}\text { 1999-2008 dönemi için } 18 \text { AB üye ülke bankasının kâr yönetimi davranışı üzerinde UFRS’nin etkisi ortaya konmaya çalışılmıştır. } \\
\text { SONUC::UFRS sonrası kârın istikrarlı gösterilmesi faaliyetinde azalma gözlemlenmiştir. }\end{array}$ \\
\hline El Sood (2012) & $\begin{array}{l}\text { ABD’de faaliyet gösteren bankaların kârın istikrarlı gösterilmesi yönünde kâr yönetimi davranışları } 2008 \text { finansal kriz dönemi için test edilmiştir. } \\
\text { SONUC:: kriz öncesi dönemde (2002-2006) kârın istikrarlı gösterilmesi gözlemlenmiştir ancak bu durum kriz döneminde (2007-2009) yok olmuş, sermaye yönetimi } \\
\text { faaliyetleri ağırlık kazanmıştır. }\end{array}$ \\
\hline $\begin{array}{ll}\text { Bushman } & \text { ve } \\
\text { Williams (2012) }\end{array}$ & $\begin{array}{l}\text { 1995-2006 dönemine ait } 23 \text { ülkeye ait bankacılık verisi ile analiz yapılarak LLP’nin kârın istikrarlı gösterilmesinin tespit edilmesindeki yeri saptanmaya çalışılmıştır. } \\
\text { SONUC: Örneklem dahilinde incelenen bankalar LLP ile kârı istikrarlı göstermektedir. Ayrıca kârın LLP'yi belirleyen önemli bir faktör olduğu da raporlanmıştır. }\end{array}$ \\
\hline
\end{tabular}


Tablo 1. (Devami)

\begin{tabular}{|c|c|}
\hline YAZAR & AŞTIRMA KONUSU VE ULAŞILAN SONUÇLAR \\
\hline Kim & $\begin{array}{l}\text { 2000-2008 dönemleri için Kore Hisse Senedi Piyasası’nda işlem gören bankaların kâr yönetimi davranışları ve bankaları bu davranışa iten sebepler belirlenmeye çalışılmıştır. } \\
\text { SONUC: } \\
\text { bankanın performansını ve kâr yönetimi davranışını etkilemektedir. Şubeler beklenenin altında kâr açıkladığında ilgili ana banka ihtiyari karşılıklar ile kâr yönetimi } \\
\text { faaliyetlerini arttırmaktadır. }\end{array}$ \\
\hline $\begin{array}{l}\text { Curcio ve } \\
\text { Hasan (2015) }\end{array}$ & $\begin{array}{l}\text { 1996-2006 dönemi için AB’ye üye olan ve olmayan ülkelerden oluşan veri setleri çerçevesinde } 491 \text { bankayı kâr yönetimi, sermaye yönetimi ve sinyal verme hipotezleri } \\
\text { kapsamında analiz etmişlerdir. Analizlerine } 2008 \text { global finansal krizinin etkilerini de eklemişlerdir. } \\
\text { sONUC:LLP aracılığıyla kârın istikrarlı gösterilmesi tüm örneklem için doğrulanmıştır. Piyasaya gelecek performans hakkında sinyal verme davranışı sadece AB'ye üye } \\
\text { olmayan ülke bankalarında gözlemlenmiştir. Kriz döneminde (2007-2010) AB üye bankalarında kâr yönetimi gözlemlenmezken, üye olmayan bankalarda kârın istikrarlı } \\
\text { gösterilmesi hipotezi reddedilememiştir. }\end{array}$ \\
\hline $\begin{array}{l}\text { Ali ve diğerleri } \\
\text { (2015) }\end{array}$ & $\begin{array}{l}\text { 2003-2010 dönemi için faizsiz bankacılık hizmeti veren bankaların kâr yönetimi davranışları sorgulanmıştır. } \\
\text { SONUC: İslami bankalarda kârın istikrarlı gösterilmesi hipotezi desteklenmiştir. UFRS’ye göre raporlama yapan bankalar, GKGMİne göre raporlama yapanlara göre daha } \\
\text { yoğun bir şekilde kâr yönetimi yapmaktadırlar. }\end{array}$ \\
\hline
\end{tabular}




\subsubsection{Kredi ve Diğer Alacaklar Değer Düşüklüğü Karşılıklarının Kârın İstikrarlı Gösterilmesi Hipotezinin Test Edilme Sürecindeki Yeri Ve Önemi}

Finansal sektör özellikle de bankacılık sektörü üzerine yapılan kârın istikrarlı gösterilmesi çalışmalarında genellikle LLP (Ahmed ve diğerleri 1999, Beaver ve Engel 1996, Greenawalt ve Sinkey Jr 1988, Ma 1988) ve menkul kıymet işlemlerinden elde edilen kâr (Beatty ve diğerleri 2002, Scholes ve diğerleri 1990) dikkate alınmakla beraber, aktiflerin menkul kıymetleştirilmesi sonucu gerçeğe uygun değer üzerinden değerlenmeleri sürecinde elde edilen getiriler, finansal araçların sınıflandırılması ve ölçülmesi çerçevesinde de kâr yönetimi tespiti yapan çalışmalar bulunmaktadır (Dechow ve diğerleri 2010, Huizinga ve Laeven 2012, Song ve diğerleri 2010).

Bankalar piyasaya kullandırdıkları kredilerin geri ödenmeme riskleri doğrultusunda bu krediler için karşılık ayırmaktadırlar. Bu süreçte banka, bilançosunda negatif karakterli bir düzenleyici hesap olan özel karşılıklar hesabında yer alan tutarı bugünkü ekonomik koşullar çerçevesinde değerlendirerek oluşturduğu kredi zarar beklentisiyle karşılaştırır. Eğer geçmiş olaylardan kaynaklanan zarar beklentileri mevcut özel karşılık hesabından yüksekse, banka ilgili fark kadar özel karşılıklar hesabını arttırır ve bu artışı gelir tablosunda yer alan kredi ve diğer alacaklar değer düşüklüğü karşılığı kısmında raporlar. Bu raporlamanın bilançodaki yansıması ise aktif düzenleyici ve negatif nitelikli bir hesap olan özel karşılıklar hesabında izlenir. Hesabın kümülatif gösterimi ise gelir tablosu hesabı olan LLP hesabında izlenir (Ronen ve Sadan 1981). Dünya uygulamaları ve ülkemiz uygulamaları incelendiğinde, denetim otoritelerinin takipteki krediler için ayrılması gereken karşılıklar için belli limitler belirledikleri görülebilir.

Ülkemizde BDDK düzenlemelerinden kisaca bahsedilecek olunursa 1985 tarihli 18955 sayılı, 1988 tarihli 19820 sayılı, 1998 tarihli 23227 sayılı, 1999 tarihli 23786 ve 23913 sayıl1, 2001 tarih ve 24416 ve 24448 sayılı, 2002 y1lı 24980 say1lı, 2005 yılı 25692 sayılı ve son olarak da günümüzde de geçerliliği süren 2006 tarihli 26333 sayılı Resmi Gazete'de yayınlanan yönetmeliklerle bankaların kredi ve diğer alacaklarına dair sınıflandırma ve bunlar için ayrılacak karşılıklara ilişkin usul ve esaslar ile karşılaşılır. İlgili yönetmeliğe (2006 yılı) göre karşı1ık kavramı ; "krediler ve diğer alacaklardan doğmuş veya doğması beklenen ancak tutarı kesin olarak belli olmayan zararların karşılanması amacıyla mali tablolarda hesaben ayrılarak gider yazılan tutarlar" olarak tanımlanmıştır. Bu kapsamda bankalar yurtdışı şubeleri de dahil olmak üzere, kredilerini ve diğer alacaklarını tahsil kabiliyetine ve borçluların kredi değerliliğine göre, bu yönetmelikte belirlenen esas ve usulleri dikkate almak suretiyle, gruplar itibariyle sınıflandırarak buna göre uygun karşılıkları ayırarak izlemek zorundadırlar. Buna göre yönetmelikte sıralanan kredi sınıfları; 1.Standart Nitelikli Krediler ve Diğer Alacaklar, 2. Yakın İzlemedeki Krediler ve Diğer Alacaklar, 3. Tahsil İmkânı Sınırlı Krediler ve Diğer Alacaklar, 4. Tahsili Şüpheli Krediler ve Diğer Alacaklar, 5. Zarar Niteliğindeki Krediler ve Diğer Alacaklar şeklindedir. Düzenlemeler çerçevesinde banka yöneticilerine üçüncü, dördüncü ve beşinci grupta sınıflanan kredi grupları için sırasıyla en az \%20, \%50 ve \%100 karşılık ayırma imkânı verilmiştir. Diğer taraftan yönetmelikle banka yöneticilerine yapılacak risk analizleri ve kredilere ilişkin öngörüler çerçevesinde kredilerin sınıflandırılmasında 
dikkate alınacak vade aşımları ya da risklilik değerlendirme kriterleri dışında üç, dört ve beşinci grup kredilerinin sınıflandırılmasında karar alabilme hakkı da tanınmıştır (BDDK, 2006). Örnek vermek gerekirse banka yönetimi gerek görürse üçüncü grupta izlenen bir krediyi dördüncü gruba kaydırabilecek, dolayısıyla karşılık ayırma süreci de buna göre şekillenecektir. Diğer bir ifadeyle, bankalar gerek kredilerin karşılık ayrılan kredi grupları arasında (üçüncü, dördüncü ve beşinci grup krediler) sınıflandırılması gerek kredilere ayrılacak karşılık tutarının belirlenmesi konusunda belli sınırlar dahilinde karar verme yetkisine sahiptirler ki bahsedildiği gibi kâr yönetimi uygulamalarını tetikleyen faktör de yöneticilere tanınan bu karar verme yetkisidir. Diğer taraftan, düzenlemeye göre bankalar, standart nitelikli ve yakın izlemedeki nakdi kredileri toplamının yüzde bir (\%1) ve teminat mektupları, aval ve kefaletleri ile diğer gayri nakdi kredileri toplamının binde ikisi $(\% 0,2)$ oranında genel karşılık ayırırlar. Tablo 2.'de özel karşılık ve genel karşılıklara ilişkin oranlar ve vade aşımı süreleri verilmiştir.

Tablo 2. Kredi ve Diğer Alacaklar İçin Ayrılan Karşılıklara İlişkin Kriterler

\begin{tabular}{|c|c|c|c|c|}
\hline $\begin{array}{l}\text { Kredi } \\
\text { Grubu }\end{array}$ & Kriter & $\begin{array}{l}\text { Vade } \\
\text { Aşımı(Gün) }\end{array}$ & $\begin{array}{l}\text { Min.Karşılık } \\
\text { Oranı }\end{array}$ & $\begin{array}{l}\text { Genel } \\
\text { Karşılıklar }\end{array}$ \\
\hline $\begin{array}{l}\text { Birinci } \\
\text { Grup }\end{array}$ & $\begin{array}{l}\text { Ödemeleri yapılan, gelecekte ödeme } \\
\text { sorunları beklenmeyen, tamamen tahsil } \\
\text { edilebilecek krediler }\end{array}$ & $<30$ & ----- & $\begin{array}{l}\text { Nakdi krediler } \\
\text { için \%1, Gayri } \\
\text { nakdi krediler } \\
\text { için \%0.2 }\end{array}$ \\
\hline İkinci Grup & 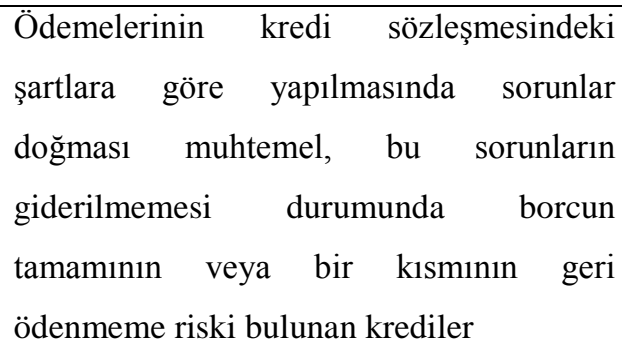 & $30-90$ & ----- & $\begin{array}{l}\text { Nakdi krediler } \\
\text { için \%2, Gayri } \\
\text { nakdi krediler } \\
\text { için \%0.4 }\end{array}$ \\
\hline $\begin{array}{l}\text { Üçüncü } \\
\text { Grup }\end{array}$ & $\begin{array}{l}\text { Borçlunun kredibilitesinin düştüğü ve son } \\
\text { zamanlarda kredi ödenme güçlükleri } \\
\text { yaşanan krediler }\end{array}$ & $90-180$ & $\% 20$ & ----- \\
\hline $\begin{array}{l}\text { Dördüncü } \\
\text { Grup }\end{array}$ & $\begin{array}{l}\text { Mevcut koşullarda geri ödenmesi veya } \\
\text { tasfiyesi muhtemel görünmeyen krediler }\end{array}$ & $180-365$ & $\% 50$ & $\begin{array}{l}---- \\
\end{array}$ \\
\hline $\begin{array}{l}\text { Beşinci } \\
\text { Grup }\end{array}$ & $\begin{array}{l}\text { Tahsilinin mümkün olmadığına kanaat } \\
\text { getirilen krediler }\end{array}$ & $>365$ & $\% 100$ & ---- \\
\hline
\end{tabular}

Kaynak: Bankalarca Kredilerin Ve Diğer Alacakların Niteliklerinin Belirlenmesi Ve Bunlar İçin Ayrılacak Karşılıklara İlişkin Usul Ve Esaslar Hakkında Yönetmelik (01.12.2006 tarihli 26333 sayılı Resmi Gazete) 


\subsubsection{Kredi ve Diğer Alacaklar Değer Düşüklüğü Karşılıkları ve Sermaye Yönetimi Uygulamaları}

LLP’nin finansal sektör açısından bir diğer önemli rolü ise bu hesabın kâr yönetimi uygulamalarına ek olarak sermaye yönetimi uygulamalarında da kullanılıyor olmasıdır. Sermaye yönetimi uygulamalarında ise LLP'nin bankalar tarafından asgari sermaye yeterliliği oranına ulaşmak için kullanıldığı görülmektedir (Anandarajan ve diğerleri 2007, Bishop ve Eccher 2000, Bouvatier ve Lepetit 2008, Kim ve Kross 1998, Leventis ve diğerleri 2011, Moyer 1990, Stinson 1994). Ancak literatürde bu çerçevede ele alınan sermaye yönetimi, bankanın sermayeyi iyi yönetmesi şeklinde değil; kâr yönetiminde olduğu gibi finansal tablo hazırlayıcılarının kredi karşılıklarını asgari sermaye yeterlilik oranına ulaşmak için manipüle etmeleri şeklinde ele alınır.

Basel uzlaşısı öncesinde (1990 öncesi) bankalar toplam aktiflerinin \%6'sı kadar toplam sermaye bulundurmak zorundaydılar. Toplam sermaye ise ödenmiş sermaye, dağıtılmamış kâr, bazı melez finansal araçlar (dönüştürülebilir borçlar) ve özel karşılıklar ve LLP'den oluşmaktayd1. Böyle bir sermaye düzenlemesi çerçevesinde LLP'deki artış sermaye yeterlilik oranında da artışa yol açmaktaydı. Bu çerçevede Basel düzenlemeleri öncesinde yapılan bazı çalışmalar LLP’nin düzenleyici sermayenin oluşumunda bir sermaye yönetimi aracı olarak kullanıldığını ortaya koymuştur. Bu çalışmaların ilki Moyer (1990) tarafından yapılmıştır. Yapılan çalışmada banka yöneticilerinin sermaye yeterlilik oranlarının denetimi esnasında karşılaşılabilecek denetim maliyetlerinden kaçınmak için, LLP’nin ihtiyaten ayrılan kısmı aracılığıyla sermaye yeterlilik oranını manipüle ettikleri raporlanmıştır.

Bishop ve Eccher (2000) ise bankaların minimum sermaye yeterlilik oranlarını ihlal etme durumunda karşılaşacakları maliyetlerin çok yüksek olması durumunda ihtiyari tahakkukların (LLP) sermaye yönetim aracı olarak kullanılacağı hipotezini öne sürmüştür.

Basel I çerçevesinde sermaye kalemleri için geliştirilen yeni kurallar altında, birinci kuşak sermaye risk ağırlıklı aktiflerin \%4'ünü ve toplam sermaye de risk ağırlıklı aktiflerin \%8'ini aşmak zorundadır. Ayrıca birinci kuşak sermaye toplam aktiflerin de en az \%3'ü kadar olmalıdır. Diğer taraftan ikinci kuşak sermaye birinci kuşak sermayeyi geçemez ve dolayısıyla toplam sermayenin en az \%50'si çekirdek ana sermayeden oluşmalıdır. Basel I düzenlemeleri ile LLP'nin ve genel karşılıkların sermaye bileşeni olarak nasıl dikkate alınacağı konusunda da değişiklikler yapılmıştır. Yeni düzenleme ile LLP artık birinci kuşak sermaye içinde yer almamaktadır. Bu kapsamda Basel düzenlemeleri öncesinde sermaye yeterlilik oranı üzerinde pozitif bir etkiye sahip olan LLP ile sermaye oranı arasındaki ilişki düzenlemeler sonrasında negatife dönmüştür. Dolayısıyla yeni düzenlemeler LLP’nin sermaye oranı üzerindeki arttırıcı etkisini ortadan kaldırmıştır (Kim ve Kross 1998).

Kim ve Kross (1998) Basel I düzenlemeleri sonrasında düşük sermayeye sahip bankaların LLP'yi azaltarak sermaye yeterlilik oranlarını yükselttiğini raporlayarak, sermaye yönetimi hipotezini destekleyen sonuçlara ulaşmışlardır. Ahmed ve diğerleri (1999) de benzer 
şekilde bankaların Basel I düzenlemeleri sonrasında LLP'yi azaltmak aracıllğıyla istenen sermaye yeterlilik oranlarına ulaştığını dolayısıyla sermaye yönetimi yapıldığını raporlamıştır.

Genel karşıllıklara ilişkin temel düzenlemeleri kabul etmekle beraber, Basel II ile genel karşılıklar ile LLP ikinci kuşak sermayeye ancak risk ağırlıklı aktiflerin en fazla \%1.25'i oranında dahil edilebilir. Eğer zarar beklentisi ayrılan karşılıkların üzerindeyse farkın \%50'si birinci kuşak sermayeden kalan kısım ise ikinci kuşak sermayeden düşülecektir. Karşılıkların zarar beklentilerinin üzerinde olması halinde ise fark ikinci kuşak sermayede risk ağırlıklı aktiflerin maksimum \%0.6'sını geçmeyecek şekilde gösterilecektir. Bu çerçevede LLP'nin birinci kuşak ve ikinci kuşak sermaye üzerinde karşııt etkileri bulunmaktadır (Ahmed ve diğerleri 1999).

Anandarajan ve diğerleri (2005) İspanya'da faaliyet gösteren yatırım bankaları ve ticari bankaları örneklem olarak inceleyen çalışmalarında LLP'nin Basel düzenlemeleri öncesinde sermaye yönetimi aracı olarak kullanıldığını ancak bu durumun düzenlemeler sonrasında gözlemlenmediğini ifade etmiş̧lerdir. Anandarajan ve diğerleri (2006) tarafindan yürütülen bir diğer çalışmada Avustralya'da faaliyet gösteren bankalar incelenmiş ve bankaların LLP'yi sermaye yönetimi aracı olarak kullandıklarını ancak bu durumun Basel düzenlemeleri öncesi ve sonrasında anlamlı bir değişim göstermediğini raporlamışlardır.

Bouvatier ve Lepetit (2008) Avrupa'da faaliyet gösteren bankalar üzerine yaptıkları çalışmada sermaye yeterlilik oranları açısından zayıf performans gösteren bankalar tarafından LLP’nin ihtiyari ayrılan kısmının sermaye yönetimi faaliyetinde kullanıldığını göstermişlerdir.

\subsection{UFRS Uygulamalarının Kâr ve Sermaye Yönetimi Üzerine Etkileri}

Yerel ve uluslararası boyutta UFRS'ye uygun finansal tablo hazırlanmaya başlanması ve bu durumun birçok ülkede artık zorunlu bir uygulama haline getirilmesiyle birlikte UFRS uygulamalarının finansal raporlama kalitesi üzerindeki etkileri de tartışılmaya başlanmıştır. Daha önce de bahsedildiği gibi bu çalışma kapsamında kâr kalitesi tahakkuk kalitesi aracılı̆̆ıyla ölçülmüş ve bu çerçevede kâr yönetimi ve sermaye yönetimi uygulamaları açısından ele alınmıştır. İlke temelli muhasebe ve finansal raporlama standartları, kural temelli yerel muhasebe ilkelerine (genel kabul görmüss muhasebe ilkeleri) göre daha büyük ölçüde piyasa odaklıdır ve finansal tablo kullanıcısıyla bilgi paylaşımına daha fazla önem verir. $\mathrm{Bu}$ kapsamda şirketin durumunu en iyi yansıtan muhasebe ölçütlerinin seçilmesini gerekli kılan muhasebe standartları kurulu ortak bir dil geliştirme amacıyla alternatif muhasebe uygulamalarının kullanımına da bir sınır getirmiştir.

Kâr ve sermaye yönetimi açısından ele alındığındaysa UFRS tarafindan getirilen en önemli yenilik saklı rezerv kullanımını yasaklayarak yöneticilerin bu konudaki insiyatiflerini büyük ölçüde kısıtlamasıdır. Bu açıdan ele alındığında UFRS'nin, yöneticilerin muhasebeleştirme seçeneklerini seçme konusundaki karar verme yetkilerini sınırlandırarak firsatçı yaklaşımlarla kâr yönetimi uygulamalarını azaltması ve bu sayede finansal 
raporlamanın güvenilirliğini arttırması beklenen bir durumdur (Ashbaugh ve Pincus 2001, Barth ve diğerleri 2008, Ewert ve Wagenhofer 2005, Jeanjean ve Stolowy 2008). Hernekadar muhasebe standartları muhasebe kalitesini sağlamayı amaçlasa da muhasebe kalitesinin muhasebe standartları tarafından mutlak bir şekilde belirlenmediğini gösteren çalışmalar bulunmaktadır (Ball ve diğerleri 2000, Ball ve Shivakumar 2005, Beatty ve diğerleri 2002, Burgstahler ve Eames 2006, Ewert ve Wagenhofer 2005, Fonseca ve González 2008, Leuz ve diğerleri 2003). Çalışmalarda muhasebe kalitesinin piyasa koşulları ve kurumsal yapı, ortaklık yapısı, denetleyici otoritenin yapısı gibi firma özellikleri nedeniyle değişiklik gösterebildiği sonuçlarına varılmıştır.

UFRS uygulamalarının kâr ve sermaye yönetimi üzerindeki etkilerine bakıldığında da bu konuda tam bir fikir birliğine ulaşılamadığı görülmektedir.Van Tendeloo ve Vanstraelen (2005)UFRS’nin kâr yönetimi üzerindeki etkisini Almanya' da faaliyet gösteren şirketler için sorgulamış ve saklı rezerv kullanım durumuna göre farklı sonuçlara ulaşmıştır. Buna göre, saklı rezerv kullanımı analizlere dahil edilmediğinde UFRS ile uyumlu raporlama yapan şirketlerin ihtiyari tahakkuklar aracılığıyla yapılan kâr yönetimi faaliyetlerini arttırdığı sonucuna ulaşılmıştır. Ancak dört büyük denetim şirketinden biri tarafindan denetlenen şirketlerde kâr yönetimine daha az rastlanılmıştır. Diğer taraftan analizlere saklı rezervler dahil edildiğinde UFRS ile uyumlu raporlama yapan şirketler ile yapmayan şirketler arasında kâr yönetimi açısından bir farklılığa ulaşılamamıştır. Benzer şekilde Jeanjean ve Stolowy (2008)UFRS uygulamalarına ilk kez geçiş yapan ülkeler olan Avustralya, Fransa ve Birleşik Krallık'ta faaliyet gösteren şirketleri incelemişler ve UFRS sonrasında kâr yönetiminde bir azalış değil, tersine Fransa örnekleminde artış raporlamışlardır.Ozili (2015) Nijerya örneklemi için yaptığı analizde UFRS sonrası dönem için bankaların LLP aracılığı ile kârı istikrarlı göstermeye devam ettikleri sonucuna ulaşmıştır.Ali ve diğerleri (2015) faizsiz bankacılık hizmeti veren bankaları incelemişler ve beklentilerin aksine UFRS'ye göre raporlama yapan bankalarda sermaye ve kâr yönetimi faaliyetlerini gözlemlerken, genel kabul görmüş muhasebe ilkelerine göre raporlama yapan bankalarda bu duruma daha az rastlamışlardır.

Diğer taraftan UFRS'e geçiş sonrası kâr ve sermaye yönetimi faaliyetlerinde düşüş gözlemleyen çalışmalar da bulunmaktadır. Barth ve diğerleri (2008) inceledikleri şirketlerde UFRS sonrası kâr yönetimi uygulamalarında anlamlı düşüşler raporlamışlardır. Leventis ve diğerleri (2011) de Avrupa'da faaliyet gösteren ve borsaya kayıtlı 91 banka üzerinde yaptıkları çalışmada UFRS'nin LLP aracılığıyla sermaye yönetiminde neden olduğu etkiyi incelemişlerdir. Yaptıkları çalışma sonucunda yüksek riskliliğe sahip bankaların daha yüksek oranlarda kayıp kredi karşılığı ayırdıklarını raporlamışlar; ancak karşılıkların sermaye yönetimi aracı olarak kullanıldığına ilişkin bir kanıt bulamamışlardır. Diğer taraftan UFRS sonrası dönemde kâr yönetimi faaliyetinde anlamlı derecede azalma da raporlamışlardır. Gebhardt ve Novotny-Farkas (2011) ise UFRS sonrası dönemde bankaların kâr yönetimi faaliyetlerinde anlamlı düşüşler gözlemlemişlerdir; ancak UFRS öncesi dönemde LLP aracılığıyla sermaye yönetimi yapıldığını destekleyen sonuçlara ulaşmazken UFRS sonrası dönemde sermaye yeterlilik oranını arttırmak için karşılıkların kullanımının arttırıldığı şeklinde sonuçlar raporlamışlardır. 


\section{VERI VE YÖNTEM}

\section{1. Örneklem, Yöntem ve Hipotezler}

Bu çalışma kapsamında Türk bankacılık sektörünün kâr yönetimi ve sermaye yönetimi davranışı üzerinde UFRS'e geçiş ve uygulama sürecinin etkisi incelenmiştir. Bu çerçevede amaçlanan ise sektörün finansal raporlama kalitesinde uluslararası standartların olumlu bir etkisi olup olmadığını ortaya koymaktır. Çalışma kapsamında yapılan bütün analizler panel veri analiz teknikleri kullanılarak "Eviews 8" istatistik ve ekonometri paket programı aracılığıyla yapılmıştır. Bu çerçevede çalışmada Türk Bankacılık sistemi içerisinde 20032015 yılları arasında faaliyette bulunmuş 23 bankanın finansal tabloları incelenmiş ve örneklem seti oluşturulmuştur. Farklı faaliyet süreçlerinden dolayı kalkınma ve yatırım bankalarının dahil edilmediği analizlerde nihai örneklem ise 299 banka-yılı veridir ${ }^{3}$.

Panel veri analizi, zaman boyutuna ait kesit verileri kullanarak ekonomik ilişkilerin tahmin edilmesini içeren bir ekonomik yöntemdir (Gujarati, 2003). Diğer bir ifadeyle panel veri analizi verileri yatay kesit ve zaman serisi bazında birleştirerek bir analiz kurgular. $\mathrm{Bu}$ çerçevede panel veri ile yapılan analizler yatay kesit ve zaman serilerinin özelliklerini de içerdiği için yatay kesit ve zaman serisi analizlerine oranla daha çok ve istatistiki anlamda daha sağlam bilgi yansıtır (Baltagi, 2008; Greene, 2003).

Panel veri analizinin yatay kesit ve zaman serisi analizlerine göre öne çıkan bazı üstün yönlerini şu şekilde sıralamak mümkündür (Baltagi, 2008):

i. $\quad$ Panel veriler kısa zaman serisi ya da yetersiz kesit gözleminin olduğu yani örneklem boyutunda sıkıntıların yaşandığı durumlarda da analiz yapılmasını mümkün kilmaktadır.

ii. Panel veri seti kesitlerin heterojen olduğu varsayımına dayanır, böylece veri seti heterojenliğe karşı kontrol edilir.

iii. Panel veri analizi, zaman serisi ve kesit veri analizlerine göre daha çok değişkenlik gösterir, bu sayede çoklu bağlantı sorunuyla daha az karşılaşılır.

iv. Panel veri analizleri bir dönem uygulanan politikaların etkilerinin değerlendirilmesinin söz konusu olduğu analizlerde değişim dinamiklerini modele daha iyi entegre eder.

Çalışmanın sadece Türk bankacılık sektörünü ele alması nedeniyle gözlem sayısı nispeten azdır, diğer taraftan örneklem içinde tüm sektör yer aldığından veri heterojen bir yapı göstermektedir (kamu/özel sermayeli bankalar, yerli/yabancı sermayeli bankalar, vb.). bu yüzden de bu kısıtları optimize etmesi açısından analizlerin yapılmasında panel regresyon yöntemi kullanılmıştır. ${ }^{3}$ Çalışmada kullanılan banka listesi Ek.1'de yer almaktadır. Veri seti talebi halinde yazarlarla iletişime
geçilebilir. 
Kâr yönetimi ve sermaye yönetiminin incelendiği çalışmaların hemen hepsinde ele alınan birincil muhasebe kalemi LLP'dir (Ahmed, Takeda, \& Thomas, 1999; Anandarajan, Hasan, \& McCarthy, 2007; Beaver \& Engel, 1996; Gebhardt \& Novotny-Farkas, 2011; Greenawalt \& Sinkey Jr, 1988; Kanagaretnam, Lobo, \& Mathieu, 2003; Kanagaretnam, Lobo, \& YANG, 2004; Leventis, Dimitropoulos, \& Anandarajan, 2011; Ma, 1988). Bu çerçevede bu çalışmada da bankacılık sektörünün kâr ve sermaye yönetimi davranışı LLP açısından ele alınarak analiz edilmiştir. Yöntemsel olarak ise çalışmaya temel oluşturan regresyon modeli kâr ve sermaye yönetiminin tespitinde çoğu çalışmada kullanılan modele (Ahmed et al., 1999; Anandarajan, Hasan, \& Lozano-Vivas, 2005; Anandarajan et al., 2007; Beatty, Ke, \& Petroni, 2002; Fonseca \& González, 2008; Kanagaretnam et al., 2004; Kim \& Kross, 1998) benzerlik gösteren Gebhardt and Novotny-Farkas (2011) tarafından kullanılan modele dayanmaktadır.

Bu çerçevede kârın istikrarlı gösterilmesi (kâr yönetimi) ve sermaye yönetiminin tespitinde ve bu iki gösterge üzerinde UFRS uygulamalarının etkisinin ortaya konulmasını amaçlayan ilgili regresyon modeli şu şekilde ifade edilebilir:

$$
\begin{aligned}
& L L P_{i t}=\alpha_{0}+\alpha_{1} N P L_{i t-1}+\alpha_{2} \Delta N P L_{i t}+\alpha_{3} \text { Loans }_{i t}+\alpha_{4} E B L L P_{i t}+\alpha_{5} I_{F R S_{i t}} \\
& +\alpha_{6} \text { Reg. } \operatorname{Cap}_{i t}+\alpha_{7} \text { EBLLP }_{i t} * I F R S_{i t}+\alpha_{8} \text { Reg. Cap } \text { Cat } * I F R S_{i t}+\varepsilon_{t}
\end{aligned}
$$

İlgili modelde bağımlı değişken LLP it, cari döneme ait LLP’yi (LLP) ifade ederken; $\mathrm{NPL}_{\mathrm{it}-1}$, takipteki kredilerin dönem başı açılış bakiyesini, $\triangle \mathrm{NPL}_{\mathrm{it}}$, takipteki krediler hesabındaki cari dönem değişimini $\left(\mathrm{NPL}_{\mathrm{it}}-\mathrm{NPL}_{\mathrm{it}-1}\right), \Delta \mathrm{Loans}_{\mathrm{it}}$, cari dönem toplam kredilerdeki değişimi ve EBLLP ${ }_{\text {it }}$ ise cari dönem LLP öncesi net kârını ifade etmektedir. Sermaye yönetiminin tespitine yönelik modele dahil edilen değişkenlerden Reg.Cap bankanın ilgili dönemdeki sermaye yeterlilik oranını ifade etmektedir. UFRS uygulamalarının kâr ve sermaye yönetimi üzerindeki etkilerinin tespiti için analize gölge değişkenler dahil edilmiştir. Bu değişkenlerden UFRS $_{\text {it }}$ bankanın ilgili dönemde UFRS’e göre raporlama yaptığı dönemler için " 1 ", yapmadığı dönemler için ise " 0 " değerlerini almaktadır. EBLLP ${ }_{\text {it }}{ }^{*} \mathrm{UFRS}_{\text {it }}$ ve Reg.Cap ${ }_{i t}{ }^{*} U_{F R S}$ it etkileşim değişkenleri ise sırasıyla kâr yönetimi ve sermaye yönetimi davranışlarının uygulanan muhasebe politikasıyla (UFRS'e göre raporlama yapma veya yapmama durumu) etkileşimini ifade etmektedir. Bu kapsamda örneğin Reg.Cap ${ }_{i t}{ }^{*} U_{F R S}$ değişkeni UFRS kullanımı sonrasında LLP’nin sermaye yönetimi amacıyla kullanılmasındaki değişimi ölçmektedir.

Bu kapsamda çalışma kapsamında kurulan hipotezler şu şekilde sıralanabilir:

Kâr yönetiminin test edilmesinde kurulan hipotez:

$\mathrm{H} 1_{0}=$ Kredi ve Diğer Alacaklar Değer Düşüklüğü Karşılıkları ile karşılık öncesi net kâr arasında bir ilişki yoktur.

Sermaye yönetiminin test edilmesinde kurulan hipotez:

$\mathrm{H}_{2}=$ Kredi ve Diğer Alacaklar Değer Düşüklüğü Karş1lıkları ile sermaye yeterlilik oranı arasında bir ilişki yoktur. 
UFRS uygulamalarının kâr yönetimi üzerindeki etkisinin test edilmesinde kurulan hipotez:

$\mathrm{H}_{0}=$ UFRS uygulamalarının kâr yönetimi üzerinde anlamlı bir etkisi yoktur.

UFRS uygulamalarının sermaye yönetimi üzerindeki etkisinin test edilmesinde kurulan hipotez:

$\mathrm{H} 4_{0}=$ UFRS uygulamalarının sermaye yönetimi üzerinde anlamlı bir etkisi yoktur.

Analiz çerçevesinde kullanılan ilgili hipotezler kapsamında test edilen temel değişkenlere ilişkin ilişki yön tahminleri içinse şu açıklamalar yapılabilir: Finansal sektörün (özellikle de bankacılık sektörü) kredi karşılıkları aracılığıyla kârı istikrarlı gösterdiğine dair geniş bir çerçevede kabul görmüş ampirik kanıtlar 1şı̆̆ında, analizler kapsamında $\alpha_{4}$ katsayısının pozitif ve anlamlı olması beklenmektedir. Bu kabul altında, bankaların kârın yüksek olduğu zamanlarda daha yüksek, kârın düşük olduğu dönemlerde ise daha düşük karşılık ayırarak kârda zamanlar arası gözlemlenebilecek dalgalanmaları azalttıkları önermesi test edilmektedir. Sermaye yönetimi davranışının test edilmesi için modele eklenen sermaye yeterlilik oranı katsayısı $\alpha_{6}$ içinse literatürle uyumlu bir şekilde (Anandarajan et al., 2007; Bouvatier, Lepetit, \& Strobel, 2014; Leventis et al., 2011) negatif sonuç beklenmektedir. Bu beklentinin nedeni ise Basel düzenlemeleri sonrasında (Basel 2 ve sonrasi) LLP'nin artık sermaye yeterlilik oranı üzerinde arttırıcı bir etkisi olmamasıdır. Ancak bu yeni düzenlemelerle LLP sermaye yeterlilik oranını dağıtılmayan kârlar aracılı̆̆ıyla dolaylı olarak etkilemektedir. LLP'nin yüksek olması göreli olarak batık kredi zararlarında artışa neden olacak; bu durum da dağıtılmayan kârları azaltacaktır (Leventis et al., 2011). Bu sürecin sermaye yeterlilik oranı üzerindeki etkisi ise negatif yönde olacaktır. Bu açıdan bakıldığında LLP ile sermaye yeterlilik oranı arasında negatif ilişki beklenmektedir. UFRS’in kâr ve sermaye yönetimi üzerindeki etkisini görmek için ele alınan etkileşim gölge değişkenleri için ise $\left(\mathrm{EBLLP}_{\mathrm{it}}{ }^{*} \mathrm{UFRS}_{\mathrm{it}} \mathrm{ve}\right.$ Reg.Cap $\left.{ }_{\mathrm{it}}{ }^{*} \mathrm{UFRS}_{\mathrm{it}}\right)$ UFRS'in raporlama kalitesinin arttıracağ beklentisi altında negatif ya da en azından UFRS öncesi etkileri de içinde barındıran $\alpha_{4}$ ve $\alpha_{6}$ katsayılarından daha düşük bir katsayı değeri beklenmektedir.

\section{AMPİRIK ANALIZ ve BULGULAR}

\subsection{Tanımlayıcı İstatistikler}

Çalışma kapsamında yapılan analizlerde kullanılan değişkenlere ilişkin özet tanımlayıcı istatistiki bilgiler Tablo 3'te Panel A'da verilmiştir. Panel B'de ise değişkenler arası Pearsonkorelasyon katsayıları yer almaktadır. Panel A'da yer alan toplam değerlere bakıldığında LLP’nin büyüklük toplam aktifler ve net kâr içindeki payının oldukça yüksek olması kâr yönetimi tespitinde karşılıkların önemli bir araç olduğu savını desteklemektedir (McNichols, 2001).

Diğer taraftan korelasyon tablosunda yer alan veriler incelendiğinde LLP ile karşılık öncesi net kâr arasında pozitif anlamlı ilişki ve LLP ile sermaye yeterlilik oranı arasında ise 
negatif ilişki saptanmıştır. $\mathrm{Bu}$ durum ampirik analizler öncesinde bankacılık sektörünün LLParacılığıyla kâr ve sermaye yönetimi davranışlarında bulunduğu beklentisini güçlendirir niteliktedir.

\subsection{Regresyon Analizi Sonuçları}

Çalışma kapsamında yapılan analizler panel regresyon teknikleri kullanılarak yapılmıştır. Panel regresyon ile analiz yapılmadan önce değişkenlerin durağan olup olmadıklarının tespiti için birim kök testlerinin yapılması gerekmektedir (Gujarati, 2003). Bu doğrultuda yapılan birim kök testleri (Im, Pesaran, \&Shin, 2003; Levin, Lin, \&Chu, 2002) sonucunda analizde kullanılan değişkenlerin durağan özellik gösterdikleri görülmüştür.

Diğer taraftan regresyon analizinde hata terimleri arasında görülebilecek değișen varyans ve otokorelasyon problemleri analiz sonuçlarını yanlış yönde etkileyebilmektedir. $\mathrm{Bu}$ problemin önüne geçmek amaciyla veride değişen varyans ya da oto korelasyon sorunu olsa bile sağlam tahminler yapılmasına olanak veren White (rassal etkiler modelinde) ya da SUR (sabit etkiler modeli) düzeltmeleri yapılmıştır (White, 1980; Wooldridge, 2010).

Tablo 3. Tanımlayıcı İstatistikler

\begin{tabular}{|c|c|c|c|c|c|c|}
\hline \\
\hline \multicolumn{5}{|c|}{ Panel A. Değişkenlere Ait Tanımlayıcı İstatistikler (bin TL) } & & \\
\hline & LLP & REG_CAP & TL & TA & NPL & EBLLP \\
\hline Ortalama & 392765.6 & 25.70456 & 23387997 & 41151797 & 780155.6 & 1076151. \\
\hline Ortanca & 129674.5 & 16.96618 & 6844700 & 12064358 & 259048.5 & 293465.5 \\
\hline Maximum & 2521496. & 148.2000 & $1.87 \mathrm{E}+08$ & $3.03 E+08$ & 6131740. & 6583024. \\
\hline Minimum & -369.0000 & 7.239254 & 2329.000 & 25564.00 & 0.000000 & -1416668. \\
\hline Std. Sap. & 554195.7 & 20.60517 & 36730782 & 60572251 & 1065449. & 1504432 \\
\hline Toplam & $1.12 \mathrm{E}+08$ & 7351.505 & $6.69 \mathrm{E}+09$ & $1.18 \mathrm{E}+10$ & $2.23 \mathrm{E}+08$ & $3.08 \mathrm{E}+08$ \\
\hline özlem Sayısı & 286 & 286 & 286 & 286 & 286 & 286 \\
\hline
\end{tabular}

Panel B. Pearson Korelasyon Tablosu

\begin{tabular}{|c|c|c|c|c|c|c|}
\hline \multicolumn{7}{|c|}{ DEĞİŞKENLER } \\
\hline & LLP & REG_CAP & TL & TA & NPL & EBLLP \\
\hline LLP & $\begin{array}{c}1.000 \\
----\end{array}$ & & & & & \\
\hline REG_CAP & $\begin{array}{c}-0.284 \\
0.00^{* * *}\end{array}$ & $\begin{array}{c}1.000 \\
----\end{array}$ & & & & \\
\hline TL & $\begin{array}{c}0.870 \\
0.00^{* * *}\end{array}$ & $\begin{array}{c}-0.285 \\
0.00^{* * *}\end{array}$ & $\begin{array}{c}1.000 \\
----\end{array}$ & & & \\
\hline TA & $\begin{array}{c}0.879 \\
0.00^{* * *}\end{array}$ & $\begin{array}{c}-0.267 \\
0.00^{* * *}\end{array}$ & $\begin{array}{c}0.986 \\
0.00^{* * *}\end{array}$ & $\begin{array}{c}1.000 \\
----\end{array}$ & & \\
\hline NPL & $\begin{array}{c}0.905 \\
0.00^{* * *}\end{array}$ & $\begin{array}{c}-0.273 \\
0.00^{* * *}\end{array}$ & $\begin{array}{c}0.866 \\
0.00^{* * *}\end{array}$ & $\begin{array}{c}0.851 \\
0.00^{* * *}\end{array}$ & $\begin{array}{c}1.000 \\
----\end{array}$ & \\
\hline EBLLP & $\begin{array}{c}0.882 \\
0.00^{* * *}\end{array}$ & $\begin{array}{c}-0.251 \\
0.00^{* * *}\end{array}$ & $\begin{array}{c}0.925 \\
0.00^{* * *}\end{array}$ & $\begin{array}{c}0.962 \\
0.00^{* * *}\end{array}$ & $\begin{array}{c}0.827 \\
0.00^{* * *}\end{array}$ & 1.00 \\
\hline
\end{tabular}

***, **, * sirasıyla \%1, \%5 ve \%10 düzeyinde istatistiksel anlamlılığ ifade etmektedir. 
Ayrıca panel regresyon tekniği ile tahmin yapılması durumunda sabit etkiler ya da rassal etkiler modellerinden hangisinin kullanılması gerektiğine kârar vermek için de Hausman (1978) test istatistiği kullanılmıştır.

Yapılan regresyon analizi sonuçları Tablo 4'de yer almaktadır. Elde edilen sonuçlar incelendiğinde Türk bankacılık sektöründe faaliyet gösteren bankaların örneklem dönemi olan 2003-2015 dönemi için LLP’yi hem kâr yönetimi hem de sermaye yönetimi amacıyla kullandıkları görülmektedir. Bu çerçevede döneme ait LLP ile karşılık öncesi net kâr arasında beklentilerle uyumlu olarak anlamlı ve pozitif iliş̧ki saptanmıştır (katsayı: 0.261, p: 0.00). Elde edilen bu sonuç 1şığında $\mathrm{H} 1_{0}$ reddedilerek, Türk bankacılık sektörünün LLP aracilığıyla kâr1 istikrarlı gösterme yönünde kâr yönetimi faaliyetinde bulunduğu söylenebilir. Dolayısıyla finansal tablo hazırlayanlar kendilerine sağlanan karar verme yetkileri çerçevesinde kârın yüksek (düşük) olduğu zamanlarda kredi karş1lıklarını (özel karşılıklar aracılığıyla) arttırarak (azaltarak) kâr trendinde istikrarlı bir görünüm elde etmektedirler. Bu sonuç kârın istikrarlı gösterilmesi hipotezini ele alan ve LLP ile kâr yönetimi faaliyeti yapıldı̆̆ını gösteren literatürle (Bao \& Bao, 2004; Bhat, 1996; Blasco \& Pelegrin, 2006; El Sood, 2012; Fonseca \& González, 2008; Kanagaretnam et al., 2004; Kilic, Lobo, Ranasinghe, \& Sivaramakrishnan, 2012; Liu \& Ryan, 2006; Rivard, Bland, \& Morris, 2003; Taktak, Shabou, \& Dumontier, 2010) de uyumludur.

Bankacılık sektörünün kâr yönetimine ek olarak sermaye yönetimi davranışının da ele alındığı bu çalışmada sermaye yönetimine ilişkin elde edilen sonuçlara göre ise, döneme ait LLP ile sermaye yeterlilik oranı arasında anlamlı negatif ilişki raporlanmıştır (katsayı: -0.0001, p:0.00). Bu sonuç 1şı̆̆ında Türk bankacıllk sektöründe LLP aracilı̆̆ıyla sermaye yönetimi faaliyetinde bulunduğu söylenebilir. Buna göre, bankalar için oldukça önemli bir denetim mekanizması olan sermaye yeterlilik oranını hedeflenen seviyelerde tutabilmek için LLP kullanılabilmektedir. Bu çerçevede sermaye yeterlilik oranında düşüş beklendiğinde finansal tablo hazırlayıcılarının belli limitler dahilinde karar verme yetkilerinin bulunduğu LLP arttırılarak oranda istenen artış sağlanabilecektir. Dolayısıyla $\mathrm{H}_{0}$ reddedilmiştir. Elde edilen bu sonuç LLP ile sermaye yeterlilik oranı arasında Basel 1 düzenlemeleri sonrasında negatif ilişki olduğunu savunan literatürle de uyum içerisindedir (Ahmed et al., 1999; Anandarajan et al., 2005; Anandarajan et al., 2007; Bouvatier \& Lepetit, 2008; Gebhardt \& Novotny-Farkas, 2011; Kim \& Kross, 1998; Leventis et al., 2011) . 
Tablo 4. Regresyon Analizi Sonuçları

$$
\begin{aligned}
& L L P_{i t}=\alpha_{0}+\alpha_{1} N P L_{i t-1}+\alpha_{2} \Delta N P L_{i t}+\alpha_{3} \Delta \text { Loans }_{i t}+\alpha_{4} E B L L P_{i t}+\alpha_{5} I F R S_{i t} \\
& +\alpha_{6} \text { Reg. }_{\text {Cap }}+\alpha_{7} \text { EBLLP }_{i t} * \text { IFRS }_{i t}+\alpha_{8} \text { Reg. } \text { Cap }_{i t} * I F R S_{i t}+\varepsilon_{t}
\end{aligned}
$$

\begin{tabular}{|c|c|c|c|}
\hline Değişken & Katsayı & Katsayı Tahmini & Model.1 \\
\hline & & & Bağımlı Değişken: LLP $P_{i t}$ \\
\hline \multirow[t]{2}{*}{ NPL $_{\text {it-1 }}$} & $\alpha_{1}$ & + & 0.312 \\
\hline & & & $\left(0.00^{* * *}\right)$ \\
\hline \multirow[t]{2}{*}{$\Delta \mathrm{NPL}_{\text {it }}$} & $\alpha_{2}$ & + & 0.340 \\
\hline & & & $(0.00 * * *)$ \\
\hline \multirow[t]{2}{*}{$\Delta$ Loans $_{\text {it }}$} & $\alpha_{3}$ & ? & -0.01 \\
\hline & & & $\left(0.03^{* *}\right)$ \\
\hline \multirow[t]{2}{*}{ EBLLP $_{\text {it }}$} & $\alpha_{4}$ & + & 0.261 \\
\hline & & & $(0.00 * * *)$ \\
\hline \multirow[t]{2}{*}{ UFRS $_{\text {it }}$} & $\alpha_{5}$ & $?$ & -0.013 \\
\hline & & & $(0.00 * * *)$ \\
\hline
\end{tabular}

$\begin{array}{lccc}\text { Reg.Cap } & \alpha_{6} & - & -0.0001 \\ \text { EBLLP }_{\text {it }} * \mathbf{U F R S}_{\text {it }} & \alpha_{7} & +,- & \left(0.00^{* * *}\right) \\ & & (\text { azalış beklentisi) } & 0.148 \\ \text { Reg.Cap }_{\text {it }}{ }^{*} \text { UFRS }_{\text {it }} & \alpha_{8} & - & \left(0.00^{* * *}\right) \\ & & \text { (azalış beklentisi) } & -4.72 \mathrm{E}-05\end{array}$

\section{Düzeltilmiş $\mathbf{R}^{2}$}

Gözlem Sayısı

0.44

Regresyon modelinde hata terimleri için White (rassal etkiler modelinde) ya da SUR (sabit etkiler modeli) düzeltmeleri yapılmıştır. p (olasılık) değerleri parantez içinde yer almaktadır. ***, **, * sırasıyla \%1, \%5 ve \%10 düzeyinde istatistiksel anlamlılığı ifade etmektedir. Değişkenlerin hepsi (UFRS gölge değişkeni, sermaye yeterlilik oranı ve ilgili gölge değişkeni hariç) bir önceki dönem toplam aktifleri ile deflate edilmiştir.

\section{Değişken Tanımları:}

$\operatorname{LLP}_{\text {it }}$, cari döneme ait Kredi ve Diğer Alacaklar Değer Düşüklüğü Karşılıkları; NPL ${ }_{\mathrm{it}-1}$, takipteki kredilerin dönem başı açılış bakiyesi; $\triangle \mathrm{NPL}_{\mathrm{it}}$, takipteki krediler hesabındaki cari dönem değişim $\left(\mathrm{NPL}_{\mathrm{it}}-\mathrm{NPL}_{\mathrm{it}-1}\right) ; \Delta \mathrm{Loans}_{\mathrm{it}}$, cari dönem toplam kredilerdeki değişim; EBLLP $_{\text {it }}$ ise cari dönem karşıllk öncesi net kâr; UFRS ${ }_{\text {it }}$, UFRS uygulanan yıllar için "1" diğer yıllar için “0”; Reg.Cap ${ }_{i t}$, sermaye yeterlilik oranı; EBLLP ${ }_{\text {it }}{ }^{*} \mathrm{UFRS}_{\mathrm{it}}, \mathrm{EBLLP}_{\mathrm{it}}$ ile muhasebe politikası (UFRS) etkileşim değişkeni (UFRS'ye geçişin LLP’nin kâr yönetimi amacıyla kullanılması üzerindeki farkı ölçmek için), Reg.Cap ${ }_{i t}{ }^{*} U_{F R S}$, Reg.Cap ${ }_{i t}$ ile muhasebe politikası (UFRS) etkileşim değişkeni (UFRS'ye geçişin LLP’nin sermaye yönetimi amacıyla kullanılması üzerindeki farkı ölçmek için)

Bu çalışmanın bir diğer önemli ayağı ise kâr yönetimi ve sermaye yönetimi üzerinde UFRS uygulamalarının nasıl bir etki yarattığını ortaya koymaya yöneliktir. Bu kapsamda elde 
edilen sonuçlar değerlendirildiğinde, UFRS'ye geçişin kâr yönetimi davranışı üzerinde azaltıcı bir etkiye sahip olduğunu söylemek mümkündür. UFRS sonrası dönemde karşılıklar ile karşlık öncesi net kâr arasındaki ilişki \%14 olarak raporlanmışıtır, bu oran UFRS öncesi karşılıklar ile karşılık öncesi net kâr arasında gerçekleşen \%26 boyutundaki ilişsiden daha düşüktür. Dolayısıyla beklentilerle uyumlu olarak UFRS'ye geçiş raporlama kalitesini ve denetim etkinliğini arttırmış ve kârın istikrarlı gösterilmesi şeklinde ele alınan kâr yönetimi faaliyetinin boyutunu azaltmıştır (Ali, M Kabir, \& Syed Abul, 2015; Barth, Landsman, \& Lang, 2008; Leventis et al., 2011; Van Tendeloo \& Vanstraelen, 2005). Bu kapsamda H3 ${ }_{0}$ da reddedilmiştir. Ancak yine de iki değişken arasındaki anlamlı pozitif ilişki UFRS sonrasında da LLP’nin kâr yönetimi amacıyla kullanıldığı savını desteklemektedir (Jeanjean \& Stolowy, 2008; Ozili, 2015).

UFRS'ye geçişin sermaye yönetimi davranışı üzerindeki etkisi incelendiğinde ise beklentilerle uyumlu olarak, karşılıkların sermaye yönetimi amacıyla kullanılması açısından UFRS öncesi ve sonrası farkı gösteren $\alpha_{8}$ katsayısı negatif olarak raporlanmıştır. Dolayısıyla UFRS sonrası dönemde karşılıklar sermaye yönetimi amacıyla daha az boyutta kullanılmıştır. Ancak elde edilen bu sonuç istatistiksel olarak anlamlı değildir. $\mathrm{Bu}$ açıdan değerlendirildiğinde UFRS uygulamalarının sermaye yönetimi davranışı üzerinde anlamlı bir etkisi bulunmamaktadır. Elde edilen bu sonuç ışığında $\mathrm{H} 4_{0}$ reddedilememiştir. Ancak çalışma kapsamında elde edilen bu sonuç LLP aracılığıyla yapılan sermaye yönetimi uygulamaları üzerinde UFRS sonrası dönemin anlamlı bir sonuca yol açmadığını raporlayan Gebhardt and Novotny-Farkas (2011) ve Leventis et al. (2011) tarafından yapılan çalışmalarla da uyumludur.

Analiz kapsamında incelenen diğer değişkenlerle ilgili olarak ise elde edilen sonuçlar şu şekilde özetlenebilir: Tablo 4'de yer alan sonuçlar incelendiğinde, LLP'nin $\left(L L P_{i t}\right)$ takipteki krediler açılış bakiyesi $\left(N P L_{i t-1}\right)$, takipteki kredilerdeki değişim $\left(\triangle N P L_{i t}\right)$ ile pozitif ve toplam krediler büyüme oranı $\left(\triangle\right.$ Loans $_{i t}$ ) ile ise negatif ilişki içinde olduğu görülmektedir. Beklentilerle uyumlu bir şekilde takipteki krediler bankaların kredi portföylerinde yer alan sorunlu kredilerini temsil etmektedir ve takipteki kredilerin artması durumunda bankaların karşılaşılabilecek zararlarla mücadele etmek için kredi karşılıklarını arttırmaları beklenen bir durumdur (Bhat, 1996; Fonseca \& González, 2008; Greenawalt \& Sinkey Jr, 1988; Hasan \& Wall, 2004; Kanagaretnam et al., 2004; Liu \& Ryan, 2006). Diğer taraftan toplam kredilerdeki değişim ile LLP arasında raporlanan negatif ilişki banka yöneticilerinin kullandırılan ilave kredilerin kalitesi (geri ödenme olasılığı) hakkında iyimser olduğunu ve bu yüzden de daha az karşılık ayırdıkları savı ile uyumludur (Bikker \& Metzemakers, 2005; Fonseca \& González, 2008; Gebhardt \& Novotny-Farkas, 2011; Laeven \& M ajnoni, 2003) . 


\section{SONUÇ ve ÖNERILER}

Çalışmada Türk Bankacılık sistemi içerinde 2003-2015 yılları arasında faaliyette bulunmuş 23 bankanın söz konusu yıllarda yayınladıkları finansal tablolar üzerinden oluşturulan veri seti EViews 8 programı ile analiz edilmiştir.

Analizin amacı Türk Bankacılık sisteminde Kredi ve Diğer Alacaklar Değer Düşüklüğü Karşılıklarının kâr yönetimi ve sermaye yönetimi amacıyla kullanılıp kullanmadığını ve UFRS uygulamalarının olası kullanımları ne yönde etkilediğini görmektir.

Analiz sonucunda bankaların ilgili dönemde Kredi ve Diğer Alacaklar Değer Düşüklüğü Karşılıklarını hem kâr yönetimi hem de sermaye yönetimi amacıyla kullandıkları sonucuna ulaşılmıştır.

Elde edilen sonuçlara göre incelenen bankalar kârlarını istikrarlı göstermek üzere Kredi ve Diğer Alacaklar Değer Düşüklüğü Karşılıklarını kullanarak kâr yönetimi faaliyetinde bulunmuşlardır.

Sermaye yönetimi açısından bakıldığında ise bankaların kendileri için kritik olan sermaye yeterlilik rasyosunu hedefledikleri seviyede tutmak üzere kredi ve diğer alacaklar değer düşüklüğü karşılığını belli limitler dahilinde kullandıkları görülmektedir.

Tespit edilen kâr yönetimi ve sermaye yönetimi uygulamalarına UFRS'nin etkisinin ne olduğuna yönelik yapılan analizde ise UFRS'nin kâr yönetimi faaliyetlerini azaltıcı etkisinin bulunduğu ancak sermaye yönetimi faaliyetlerine anlamlı düzeyde bir etkisinin bulunmadığı sonucuna ulaşılmıştır.

\section{KAYNAKLAR}

Ahmed, A. S.- C. Takeda- S. Thomas. (1999), "Bank Loan Loss Provisions: A Reexamination of Capital Management, Earnings Management and Signaling Effects", Journal of Accounting and Economics, 28, pp.1-25.

Ali, A.- H. M Kabir- B. Syed Abul. (2015), "Loan Loss Provisioning in Oic Countries: Evidence from Conventional Vs. Islamic Banks", Cell, 704, pp.724-6490.

Anandarajan, A.- I. Hasan- A. Lozano-Vivas. (2005), "Loan Loss Provision Decisions: An Empirical Analysis of the Spanish Depository Institutions", Journal of International Accounting, Auditing and Taxation, 14, pp.55-77.

Anandarajan, A.- I. Hasan- C. McCarthy (2007), "Use of Loan Loss Provisions for Capital, Earnings Management and Signalling by Australian Banks", Accounting \& Finance, 47, pp.357-379.

Anderson, R. C. - D. R. Fraser ,2000, "Corporate Control, Bank Risk Taking, and the Health of the Banking Industry", Journal of Banking \& Finance, 24, pp.1383-1398.

Ashbaugh, H.- M. Pincus. 2001, "Domestic Accounting Standards, International Accounting Standards, and the Predictability of Earnings", Journal of accounting research, 39, pp.417-434. 
Ball, R., S. Kothari- A. Robin. 2000, "The Effect of International Institutional Factors on Properties of Accounting Earnings", Journal of accounting and economics, 29, pp.151.

Ball, R.- L. Shivakumar. 2005. "Earnings Quality in Uk Private Firms: Comparative Loss Recognition Timeliness", Journal of accounting and economics, 39, pp.83-128.

Bannister, J. W.- H. A. Newman. 1996. "Accrual Usage to Manage Earnings toward Financial Analysts' Forecasts", Review of Quantitative Finance and Accounting, 7, pp.259-278.

Bao, B. H.- D. H. Bao. 2004. "Income Smoothing, Earnings Quality and Firm Valuation", Journal of Business Finance \& Accounting, 31, pp.1525-1557.

Barth, M. E.- W. R. Landsman- M. H. Lang. 2008. "International Accounting Standards and Accounting Quality", Journal of accounting research, 46, pp.467-498.

Beatty, A.- S. L. Chamberlain- J. Magliolo. 1995. "Managing Financial Reports of Commercial Banks: The Influence of Taxes, Regulatory Capital, and Earnings", Journal of Accounting Research, pp.231-261.

Beatty, A. L.- B. Ke- K. R. Petroni. 2002. "Earnings Management to Avoid Earnings Declines across Publicly and Privately Held Banks", The Accounting Review, 77, pp.547-570.

Beaver, W. H.- E. E. Engel. 1996. "Discretionary Behavior with Respect to Allowances for Loan Losses and the Behavior of Security Prices", Journal of Accounting and Economics, 22, pp.177-206.

Beidleman, C. R. 1973. "Income Smoothing: The Role of Management", The Accounting Review, 48, pp.653-667.

Bhat, G.- J. A. Lee- S. G. Ryan. 2014. "Using Loan Loss Indicators by Loan Type to Sharpen the Evaluation of the Determinants and Implications of Banks' Loan Loss Accruals", Available at SSRN 2490670,

Bhat, V. N. 1996. "Banks and Income Smoothing: An Empirical Analysis", Applied Financial Economics, 6, pp.505-510.

Bishop, M. L.- E. A. Eccher. 2000. "Do Markets Remember Accounting Changes? An Examination of Subsequent Years", An Examination of Subsequent Years (March 17, 2000),

Blasco, N.- B. Pelegrin. 2006. "A New Methodological Approach for Detecting Income Smoothing in Small Samples: An Application to the Case of Spanish Savings Banks", Journal of Accounting, Auditing \& Finance, 21, pp.347-372.

Boonlert-U-Thai, K.- G. K. Meek- S. Nabar. 2006. "Earnings Attributes and InvestorProtection: International Evidence", The International Journal of Accounting, 41, pp.327-357.

Bouvatier, V.- L. Lepetit. 2008. "Banks’ Procyclical Behavior: Does Provisioning Matter?", Journal of International Financial Markets, Institutions and Money, 18, pp.513-526.

Bradshaw, M. T.- S. A. Richardson- R. G. Sloan. 2001. "Do Analysts and Auditors Use Information in Accruals?", Journal of Accounting research, 39, pp.45-74. 
Breton, G.- H. Stolowy. 2000. "A Framework for the Classification of Accounts Manipulations", HEC Accounting \& Management Control Working Paper,

Burgstahler, D.- M. Eames. 2006. "Management of Earnings and Analysts' Forecasts to Achieve Zero and Small Positive Earnings Surprises", Journal of Business Finance \& Accounting, 33,pp. 633-652.

Bushman, R. M.- A. J. Smith. 2001. "Financial Accounting Information and Corporate Governance", Journal of accounting and Economics, 32, pp.237-333.

Bushman, R. M.- C. D. Williams. 2012. "Accounting Discretion, Loan Loss Provisioning, and Discipline of Banks’ Risk-Taking", Journal of Accounting and Economics, pp. 54, 118.

Cahan, S. F. 1992. "The Effect of Antitrust Investigations on Discretionary Accruals: A Refined Test of the Political-Cost Hypothesis", Accounting Review, pp.77-95.

Callao, S.- J. I. Jarne- D. Wróblewski. 2014. "The Development of Earnings Management Research", Zeszyty Teoretyczne Rachunkowosci, 79,

Cavallo, M.- G. Majnoni 2002. Do Banks Provision for Bad Loans in Good Times? Empirical Evidence and Policy Implications, Springer.

Collins, J. H.- D. A. Shackelford- J. M. Wahlen. 1995. "Bank Differences in the Coordination of Regulatory Capital, Earnings, and Taxes", Journal of accounting research, 263-291.

Copeland, R. M. 1968. "Income Smoothing", Journal of Accounting Research, pp.101-116.

Curcio, D.- I. Hasan. 2008. "Earnings-and Capital-Management and Signaling: The Use of Loan-Loss Provisions by European Banks", www. efmaefm. org/0EFMAMEETINGS/EFMA\% 20ANNUAL\% 20MEETINGS/2009milan/EFMA2009_0324_fullpaper. pdf,

Curcio, D.- I. Hasan. 2015. "Earnings and Capital Management and Signaling: The Use of Loan-Loss Provisions by European Banks", The European Journal of Finance, 21, pp.26-50.

Dechow, P. M. 1994. "Accounting Earnings and Cash Flows as Measures of Firm Performance: The Role of Accounting Accruals", Journal of accounting and economics, 18, pp.3-42.

Dechow, P. M.- I. D. Dichev. 2002. "The Quality of Accruals and Earnings: The Role of Accrual Estimation Errors", The accounting review, 77, pp.35-59.

Dechow, P. M.- L. A. Myers- C. Shakespeare. 2010. "Fair Value Accounting and Gains from Asset Securitizations: A Convenient Earnings Management Tool with Compensation Side-Benefits", Journal of accounting and economics, 49, 2-25.

Dechow, P. M.- D. J. Skinner. 2000. "Earnings Management: Reconciling the Views of Accounting Academics, Practitioners, and Regulators", Accounting Horizons, 14, pp.235-250.

DeFond, M. L.- J. Jiambalvo. 1994. "Debt Covenant Violation and Manipulation of Accruals", Journal of Accounting and Economics, 17, pp.145-176.

DeFond, M. L.- C. W. Park. 1997. "Smoothing Income in Anticipation of Future Earnings", Journal of accounting and economics, 23, pp.115-139. 
El Sood, H. A. 2012. "Loan Loss Provisioning and Income Smoothing in Us Banks Pre and Post the Financial Crisis", International Review of Financial Analysis, 25, pp.64-72.

Epstein, B. J.- A. A. Mirza 1997. Interpretation and Application of International Accounting Standards, 1997, Wiley.

Ewert, R.- A. Wagenhofer. 2005. "Economic Effects of Tightening Accounting Standards to Restrict Earnings Management", The Accounting Review, 80, pp.1101-1124.

Fonseca, A. R.- F. González. 2008. "Cross-Country Determinants of Bank Income Smoothing by Managing Loan-Loss Provisions", Journal of Banking \& Finance, 32, pp.217-228.

Francis, J.- R. LaFond- P. M. Olsson- K. Schipper. 2004. "Costs of Equity and Earnings Attributes", The accounting review, 79, pp.967-1010.

Fudenberg, D.- J. Tirole. 1995. "A Theory of Income and Dividend Smoothing Based on Incumbency Rents", Journal of Political economy, pp.75-93.

Gebhardt, G. u.- Z. Novotny-Farkas. 2011. "Mandatory Ifrs Adoption and Accounting Quality of European Banks", Journal of business finance \& accounting, 38, pp.289333.

Greenawalt, M. B.- J. F. Sinkey Jr. 1988. "Bank Loan-Loss Provisions and the IncomeSmoothing Hypothesis: An Empirical Analysis, 1976-1984", Journal of Financial Services Research, 1, pp.301-318.

Hasan, I.- L. D. Wall. 2004. "Determinants of the Loan Loss Allowance: Some Cross-Country Comparisons", Financial review , 39, pp.129-152.

Holthausen, R. W. 1990. "Accounting Method Choice: Opportunistic Behavior, Efficient Contracting, and Information Perspectives", Journal of accounting and economics, 12, pp.207-218.

Huizinga, H.- L. Laeven. 2012. "Bank Valuation and Accounting Discretion During a Financial Crisis", Journal of Financial Economics, 106, pp.614-634.

Imhoff, E. A. 1979. "Income Smoothing: An Analysis of Critical Issues",

Jeanjean, T.- H. Stolowy. 2008. "Do Accounting Standards Matter? An Exploratory Analysis of Earnings Management before and after Ifrs Adoption", Journal of accounting and public policy, 27, pp.480-494.

Jermakowicz, E. K. 2004. "Effects of Adoption of International Financial Reporting Standards in Belgium: The Evidence from Bel-20 Companies", Accounting in Europe, 1, pp.51-70.

Kanagaretnam, K.- G. J. Lobo- R. Mathieu. 2003. "Managerial Incentives for Income Smoothing through Bank Loan Loss Provisions", Review of Quantitative Finance and Accounting, 20, pp.63-80.

Kanagaretnam, K.- G. J. Lobo- D. H. YANG. 2004. "Joint Tests of Signaling and Income Smoothing through Bank Loan Loss Provisions*", Contemporary Accounting Research, 21, pp.843-884.

Kim, E.-J. 2013. "Why Do Main Banks Manage Earnings?: Client Firms' Perspective", 
Kim, M.-S.- W. Kross. 1998. "The Impact of the 1989 Change in Bank Capital Standards on Loan Loss Provisions and Loan Write-Offs", Journal of Accounting and Economics, 25, pp.69-99.

Kwak, W.- H.-Y. Lee- V. Mande. 2009. "Institutional Ownership and Income Smoothing by Japanese Banks through Loan Loss Provisions", Review of Pacific Basin Financial Markets and Policies, 12, pp.219-243.

Leuz, C.- D. Nanda- P. D. Wysocki. 2003. "Earnings Management and Investor Protection: An International Comparison", Journal of financial economics, 69, pp.505-527.

Leventis, S.- P. E. Dimitropoulos- A. Anandarajan. 2011. "Loan Loss Provisions, Earnings Management and Capital Management under Ifrs: The Case of Eu Commercial Banks", Journal of Financial Services Research, 40, pp.103-122.

Lobo, G. J.- D.-H. Yang. 2001. "Bank Managers' Heterogeneous Decisions on Discretionary Loan Loss Provisions", Review of Quantitative Finance and Accounting, 16, 223-250.

Ma, C. K. 1988. "Loan Loss Reserves and Income Smoothing: The Experience in the Us Banking Industry", Journal of Business Finance \& Accounting, 15, pp.487-497.

Martinez, A. L.- M. A. R. Castro. 2011. "The Smoothing Hypothesis, Stock Returns and Risk in Brazil", BAR-Brazilian Administration Review, 8, 1-20.

McNichols, M. 2002. "Discussion of the Quality of Accruals and Earnings: Multiples", Journal of Accounting Research, 40, pp.135-172.

Michelson, S. E.- J. Jordan-W agner - C. W. Wootton. 1995. "A Market Based Analysis of Income Smoothing", Journal of Business Finance \& Accounting, 22, pp.1179-1193.

Moyer, S. E. 1990. "Capital Adequacy Ratio Regulations and Accounting Choices in Commercial Banks", Journal of Accounting and Economics, 13, pp.123-154.

Mulford, C. W.- E. E. Comiskey 2011. The Financial Numbers Game: Detecting Creative Accounting Practices, John Wiley \& Sons.

Ozili, P. K. 2015. "Loan Loss Provisioning, Income Smoothing, Signaling, Capital Management and Procyclicality: Does Ifrs Matter? Empirical Evidence from Nigeria", Mediterranean Journal of Social Sciences, 6, 224-232.

Pérez, D.- V. Salas-Fumás- J. Saurina. 2008. "Earnings and Capital Management in Alternative Loan Loss Provision Regulatory Regimes", European Accounting Review, 17, pp.423-445.

Plenborg, T. 1996. The Information Content of Accrual and Cash Flow Based Performance Measures: From a Danish and a Us Perspective, Copenhagen Business School, Department of Accounting and Auditing.

Rahman, A., J. Yammeesri ve H. Perera. 2010. "Financial Reporting Quality in International Settings: A Comparative Study of the USA, Japan, Thailand, France and Germany", The International Journal of Accounting, 45, pp.1-34.

Richardson, S. A.- R. G. Sloan- M. T. Soliman- I. Tuna. 2005. "Accrual Reliability, Earnings Persistence and Stock Prices", Journal of accounting and economics, 39, pp.437-485. 
Rivard, R. J.- E. Bland- G. B. H. Morris. 2003. "Income Smoothing Behavior of Us Banks under Revised International Capital Requirements", International Advances in Economic Research, 9, pp.288-294.

Ronen, J.- S. Sadan 1981. Smoothing Income Numbers: Objectives, Means, and Implications, Addison-Wesley Publishing Company.

Scheiner, J. H. 1981. "Income Smoothing: An Analysis in the Banking Industry", Journal of Bank Research, 12, pp.1919-2123.

Scholes, M. S.- G. P. Wilson- M. A. Wolfson. 1990. "Tax Planning, Regulatory Capital Planning, and Financial Reporting Strategy for Commercial Banks", Review of financial Studies, 3, pp.625-650.

Shrieves, R. E.- D. Dahl. 2003. "Discretionary Accounting and the Behavior of Japanese Banks under Financial Duress", Journal of Banking \& Finance, 27, pp.1219-1243.

Sloan, R. 1996. "Do Stock Prices Fully Reflect Information in Accruals and Cash Flows About Future Earnings?(Digest Summary)", Accounting review, 71, pp.289-315.

Song, C. J.- W. B. Thomas- H. Yi. 2010. "Value Relevance of Fas No. 157 Fair Value Hierarchy Information and the Impact of Corporate Governance Mechanisms", The Accounting Review, 85, pp. 1375-1410.

Stinson, C. H. 1994. The Management of Provisions and Allowances in the Savings and Loan Industry, UMI.

Stolowy, H.- G. Breton. 2004. "Accounts Manipulation: A Literature Review and Proposed Conceptual Framework", Review of Accounting and Finance, 3,pp. 5-92.

Street, D. L.- N. B. Nichols- S. J. Gray. 2000. "Assessing the Acceptability of International Accounting Standards in the Us: An Empirical Study of the Materiality of Us Gaap Reconciliations by Non-Us Companies Complying with Iasc Standards", The International Journal of Accounting, 35, pp.27-63.

Tarca, A. 2004. "International Convergence of Accounting Practices: Choosing between Ias and Us Gaap", Journal of International Financial Management \& Accounting, 15, pp.60-91.

Temiz, H.- M. Acar- M. Ö. İpci. 2016. "Reel Sektör Ve Finans Sektöründe Kar Yönetimi Uygulamaları: Literatür Taraması", World of Accounting Science, 18, ss.237-268.

Trueman, B.- S. Titman. 1988. "An Explanation for Accounting Income Smoothing", Journal of accounting research, pp.127-139.

Van Tendeloo, B.- A. Vanstraelen. 2005. "Earnings Management under German Gaap Versus Ifrs", European Accounting Review, 14, pp.155-180.

White, G. E. 1970. "Discretionary Accounting Decisions and Income Normalization", Journal of Accounting Research, 8, pp.260-273. 
EK 1. Analizlerde Kullanılan Bankalar Listesi

Türkiye Cumhuriyeti Ziraat Bankası A.Ş.

Türkiye Halk Bankası A.Ş.

Türkiye Vakıflar Bankası T.A.O.

Adabank A.Ş.

Akbank T.A.Ş.

Alternatif Bank A.Ş.

Anadolubank A.Ş.

Denizbank A.Ş.

Finans Bank A.Ş.

Oyak Bank A.Ş.

Şekerbank T.A.Ş.

Tekfenbank A.Ş.

Tekstil Bank

Turkish Bank A.Ş.

Türk Ekonomi Bankası A.Ş.

Türkiye Garanti Bankası A.Ş.

Türkiye İş Bankası A.Ş.

Yapı ve Kredi Bankası A.Ş.

Arap Türk Bankası A.Ş.

Bank Mellat

Citibank A.Ş.

Deutsche Bank A.Ş.

Habib Bank Limited

HSBC Bank A.Ş.

JPMorgan Chase Bank

SociétéGénérale (SA) 
